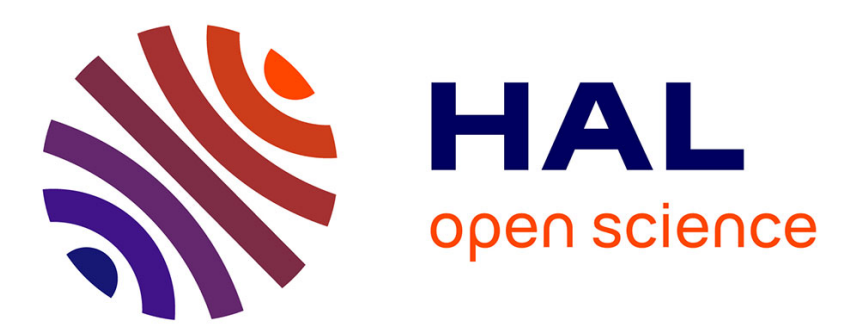

\title{
Is there a Strategy in China's Health Official Development Assistance to African Countries?
}

Marlène Guillon, Jacky Mathonnat

\section{To cite this version:}

Marlène Guillon, Jacky Mathonnat. Is there a Strategy in China's Health Official Development Assistance to African Countries?. Revue d'Economie Politique, 2019, 129 (4), pp.619. 10.3917/redp.294.0619 . hal-03157281

\section{HAL Id: hal-03157281 \\ https://hal.uca.fr/hal-03157281}

Submitted on 28 Oct 2021

HAL is a multi-disciplinary open access archive for the deposit and dissemination of scientific research documents, whether they are published or not. The documents may come from teaching and research institutions in France or abroad, or from public or private research centers.
L'archive ouverte pluridisciplinaire HAL, est destinée au dépôt et à la diffusion de documents scientifiques de niveau recherche, publiés ou non, émanant des établissements d'enseignement et de recherche français ou étrangers, des laboratoires publics ou privés. 
Is there a strategy in China's health official development assistance to African countries?

Marlène Guillon ${ }^{1}$ and Jacky Mathonnat ${ }^{2}$

${ }^{1}$ marlene.guillon@umontpellier.fr. Corresponding author. Montpellier Recherche en Economie, Université de Montpellier. Avenue Raymond Dugrand, 34960 Montpellier Cedex 2. +33(0)4 34432491.

2 jacky.mathonnat@uca.fr. Emeritus professor. Université Clermont Auvergne, CNRS, CERDI. 63-65 boulevard François Mitterrand, 63000 Clermont-Ferrand. +33(0)4 73177403. 


\begin{abstract}
China now ranks among the top ten bilateral donors for health official development assistance (ODA) in Africa. Our objective is to study the factors associated with Chinese health ODA to Africa in the 2006-2013 period. Chinese health ODA is measured using the AidData's Global Chinese Official Finance Dataset, 2000-2014, Version 1.0. In total, 345 health aid projects were financed by China in Africa between 2006 and 2013, accounting for a total amount of 2014 US\$764 million. Over the 2006-2013 period, Chinese health aid appears responsive to the economic needs of African countries and unrelated to the quality of their governance. While we find that China favors countries with limited ability to finance health projects, Chinese health aid allocation is poorly related to direct health needs of African countries. We find no evidence that Chinese health aid is directed to natural resources-rich countries while our results indicate the existence of an association between economic ties with China and the volume of Chinese health ODA received. Finally, our results confirm the idea that health aid might me used by China as part of its foreign policy since non-adherence to the one-China policy makes the receipt of Chinese health aid very unlikely.
\end{abstract}

\title{
Résumé
}

La Chine fait désormais partie des dix plus grands donateurs bilatéraux pour l'aide publique au développement (APD) en santé en Afrique. Notre objectif est d'étudier les facteurs associés à l'aide à en Afrique sur la période 2006-2013. L'APD en santé de la Chine est mesurée à partir de la base de données «AidData's Global Chinese Official Finance Dataset, 20002014, Version $1.0 »$. Au total, 345 projets d'aide à la santé ont été financés par la Chine en Afrique entre 2006 et 2013 pour un montant total de 764 millions de dollars. L'aide à la santé chinoise apparait réactive aux besoins économiques des pays africains et indépendante de la qualité de leur gouvernance politique. Bien que la Chine semble favoriser les pays ayant une faible capacité à financer des projets en santé, l'aide à la santé chinoise n'est pas corrélée aux mesures directes de besoin en santé des pays africains. Nous ne trouvons pas de preuve forte que l'aide à la santé chinoise soit liée aux dotations en ressources naturelles des pays bénéficiaires. En revanche, nos résultats indiquent l'existence d'une association entre les liens commerciaux avec la Chine et le volume d'aide à la santé reçu par les pays africains. Enfin, nos résultats confirment que la Chine utilise son APD comme un instrument de politique étrangère.

Titre en français: Y a-t-il une stratégie dans l'aide publique au développement en santé de la Chine en Afrique?

Keywords: Health aid; aid allocation; China; Africa.

Mots-clés: Aide à la santé ; allocation de l'aide ; Chine ; Afrique.

JEL classification: F35; I15. 


\section{Introduction}

"Ensure healthy lives and promote well-being for all at all ages" is one of the main Sustainable Development Goals (Goal 3). Health aid has risen sharply in the last decade; but health remains largely underfunded, particularly in Africa, and requires a specific effort in international aid (Addis-Abbeba Agenda, 2015). Until the 90's, Official Development Assistance (ODA) mainly came from Development Assistance Countries (DAC) of OECD (Organisation for Economic Cooperation and Development). For two decades, new donors, including China, have emerged in parallel to traditional DAC donors. Since the beginning of the 2000's, Chinese health ODA to Africa has largely increased. More specifically, the Chinese aid policy toward African countries shifted after the third Forum on China-Africa Cooperation (FOCAC) in 2006. Several specific announcements were made during this forum, including the doubling of China's assistance to Africa by 2009. During the third FOCAC, China also pledged to deepen its health cooperation with Africa by building hospitals and malaria prevention centers on the continent (Kjøllesdal et al., 2010; Declaration of the Beijing Summit of the Forum on China-Africa Cooperation, 2006/11/05). In 2006 was also released the "China's African Policy" document ${ }^{3}$ that aimed to shape China's aid and investment policies in Africa (Lin et al., 2016). This document specifically called for an increase of medical and public health exchanges and cooperation with African countries. In particular it mentioned increased cooperation "in the prevention and treatment of infectious diseases including HIV/AIDS and malaria and other diseases" but also in "research and application of traditional medicine and experience concerning mechanism for public health emergencies".

Our objective is to study the factors associated with Chinese health ODA to African countries between 2006 and 2013. We focus on the period after the third FOCAC, i.e. after 2006, given the global shift in Chinese aid policy to Africa at this date. We exclude year 2014 from the analysis despite data availability given the atypical pattern of Chinese health aid this year following the Ebola crisis in Guinea, Liberia and Sierra Leone ${ }^{4}$. We chose to concentrate the analysis on the health sector for several reasons. First, African countries remain in great needs of external health financing and China has become a major actor of health aid to Africa in the past decade. Indeed, China nowadays ranks among the top ten bilateral donors for health aid in Africa (Grépin et al., 2014). Moreover, health was the first sector of Chinese ODA to Africa in terms of number of projects over the 2006-2013 period with $32.5 \%$ of all ODA projects ${ }^{5}$. Given the importance of the health sector in total Chinese aid to African countries, it appears relevant to focus on the determinants of Chinese health ODA to Africa. Second, China is often seen as allocating its ODA in its own interests in order to secure its access to natural resources, to favor its exports to emerging markets or to extend its political influence (Naim, 2007; Youde, 2010; Lin et al., 2016). On the contrary, China declares allocating its ODA in response to the needs expressed by the recipient countries, according to a "win-win" strategy and following a noninterference principle (Lin et al., 2016, Second White Paper on China's Foreign Aid, 2014).

\footnotetext{
${ }^{3}$ Available at: http://www.focac.org/eng/zt/zgdfzzcwj/t230479.htm

${ }^{4}$ In 2014, almost half of Chinese health ODA projects to Africa (14/33) were related to Ebola crisis response.

${ }^{5}$ The second sector of Chinese ODA to Africa between 2006 and 2013 is education with only $13.6 \%$ of total ODA projects over the period.
} 
Moreover, at the third FOCAC in 2006, Chinese leaders highlighted the principle of "mutual benefits" as an objective of the China-Africa cooperation (Kjøllesdal et al., 2010; Declaration of the Beijing Summit of the Forum on China-Africa Cooperation, 2006/11/05). Between these two opposite discourses, Chinese motivations for aid allocation might differ depending on the ODA sector considered. China has fewer explicit economic interests in the health sector compared to other areas such as the energy or the transportation sectors. Then, Chinese motivations behind aid allocation are most likely to be related to the needs of African countries in the health sector. In other words, if altruism at least partially drives Chinese aid allocation decisions, it should be specifically observed in the health sector. On the other hand, if Chinese aid allocation decisions in the health sector are found biased towards economic and political self-interests, this is most likely to be the case for other economic and production-related sectors where Chinese Foreign Direct Investments (FDI) have surged in the past 20 years.

Three recent studies have investigated the determinants of Chinese aid allocation. However, these studies either focused on all-sectors ODA (Dreher et al., 2018) or on the period before 2006 (Dreher and Fuchs, 2015). One study specifically analyzed Chinese health ODA to African countries between 2000 and 2014. However, this study only provided a descriptive analysis of Chinese health aid (Grépin et al., 2014). Moreover, none of these studies has investigated the factors associated with Chinese health aid by type of health projects while the motivations behind aid allocation might differ for the sending of medical teams and the financing of costly health infrastructures. Following the literature on aid allocation, we investigate the role of three kinds of factors that might influence the allocation of Chinese health aid over the 2006-2013 period: the needs of the recipient countries, their merits and the self-interest of China. In a first step, we study the factors associated with the number of health projects and the amount of health ODA received by each African country. For the number of health projects, the analysis is stratified by types of projects (medical teams, infrastructure and medical equipment or drugs projects). In a second step, we study the shares, rather than the absolute values, of Chinese health ODA projects and amount received by each country.

In total, 345 health aid projects were financed by China in Africa between 2006 and 2013, accounting for a total amount of 2014 US\$764 million. Over the 2006-2013 period, our results show that Chinese health aid allocation was more responsive to economic needs than health needs of African countries. In line with the non-interference principle advocated by China, we also find that governance of recipient countries did not influence the volume of Chinese health ODA they received. Using several measures of natural resources endowment of recipient countries, we find no evidence that Chinese health aid allocation decisions favored natural resources-rich countries. Looking at the link between trade and aid, results of regression analyses point to an association between the openness rate to China and the volume of Chinese health ODA received. Finally, the allocation of Chinese health aid appears to be strongly associated with some aspects of its foreign policy since countries which chose to maintain diplomatic relationships with Taiwan were almost entirely excluded from Chinese health aid programs. 


\section{Data}

\subsection{Chinese health ODA to African countries}

Chinese health ODA is measured using the AidData's Global Chinese Official Finance Dataset, 2000-2014, Version 1.0 (Dreher et al., 2017). The database provides a detailed description of each project that includes the source of funding, the donor intent, the grant element, the flow class $\left(\mathrm{ODA}^{6}\right.$, OOF or vague), the date of the project, the recipient country, the sector of the project, the status of the project (pledged, committed, in implementation, completed, suspended or cancelled) and the value of the associated funding in $2014 \$$. From this database, we selected Chinese ODA projects in the sector of health. We chose to exclude projects that were only pledged or committed and for which no proof of money disbursement is available. Indeed, some projects might have been pledged or committed but not implemented because of a change in the economic or political relations between China and the recipient country. Suspended or cancelled projects were also excluded so that only completed or currently implemented projects are retained in the analysis. For infrastructure projects, several years may run between the project pledge, its start and the end of the project. In that case, we use the year of construction start or the year of money disbursement as the date of the project in the main analysis. If unavailable, the agreement year of the formal signed commitment is used.

Table 1 describes the number, the type and the amount of health ODA projects financed by China in Africa over the 2006-2013 period. In total, 345 health aid projects were financed by China in Africa between 2006 and 2013, accounting for a total amount of 2014 US\$764 million. On these 345 projects, $143(41.4 \%)$ correspond to the dispatch of medical teams, 107 (31\%) to the sending of medical equipment or drugs and $76(22 \%)$ to health infrastructures construction or rehabilitation.

\begin{tabular}{|l|c|c|c|c|c|c|c|c|c|}
\cline { 2 - 9 } \multicolumn{1}{c|}{} & 2006 & 2007 & 2008 & 2009 & 2010 & 2011 & 2012 & 2013 & $2006-13$ \\
\hline Health ODA projects & 31 & 39 & 48 & 68 & 44 & 45 & 31 & 39 & 345 \\
\hline Health ODA projects (\% of ODA projects) & 23.1 & 24.7 & 38.1 & 41.7 & 38.9 & 33.1 & 24.6 & 37.1 & 32.5 \\
\hline Medical teams (\% of health ODA projects) & 38.7 & 33.3 & 41.7 & 23.5 & 45.5 & 55.6 & 54.8 & 51.3 & 41.4 \\
\hline Infrastructures (\% of health ODA projects) & 9.68 & 15.4 & 31.3 & 44.1 & 13.6 & 13.3 & 9.68 & 17.9 & 22.0 \\
\hline $\begin{array}{l}\text { Medical equipment \& drugs } \\
\text { (\% of health ODA projects) }\end{array}$ & 41.9 & 46.2 & 20.8 & 22.1 & 38.6 & 26.7 & 35.5 & 28.2 & 31.0 \\
\hline Health ODA amount (millions, 2014 US\$) & 16.4 & 12.8 & 107.5 & 123.9 & 145.2 & 142.1 & 3.6 & 212.7 & 764.0 \\
\hline Health ODA amount (\% of DAC commitments) & 1.2 & 0.8 & 6.1 & 6.5 & 7.8 & 7.8 & 0.2 & 11.0 & 5.3 \\
\hline
\end{tabular}

Table 1: Number, type and amount of health projects

Table 2 presents the ranking of African countries by number of health projects and amount of health ODA received between 2006 and 2013.

\footnotetext{
${ }^{6}$ The classification of flows as ODA is similar to that of OECD. A flow is classified as ODA-like if it 1) is official financing; 2) has a development purpose and 3 ) is concessional with a grant element of at least 25 percent.
} 


\begin{tabular}{|c|c|c|c|c|c|c|c|c|c|c|c|c|c|c|}
\hline \multicolumn{3}{|c|}{ Projects } & \multicolumn{3}{|c|}{ Medical team } & \multicolumn{3}{|c|}{ Medical equip. and drug } & \multicolumn{3}{|c|}{ Infrastructures } & \multicolumn{3}{|c|}{ Health ODA amount } \\
\hline Country & Number & $\%$ & Country & Number & $\%$ & Country & Number & $\%$ & Country & Number & $\%$ & Country & Amount & $\%$ \\
\hline UG & 17 & 4.9 & TZ & 9 & 6.3 & $L R$ & 9 & 8.4 & CF & 4 & 5.3 & KE & $146,739,696$ & 19.2 \\
\hline LR & 15 & 4.3 & ZM & 8 & 5.6 & UG & 9 & 8.4 & KE & 4 & 5.3 & NE & $143,147,664$ & 18.7 \\
\hline $\mathrm{NE}$ & 15 & 4.3 & TD & 5 & 3.5 & NE & 9 & 8.4 & CG & 3 & 3.9 & $\mathrm{Cl}$ & $106,073,032$ & 13.9 \\
\hline GH & 14 & 4.1 & ER & 5 & 3.5 & $\mathrm{GH}$ & 6 & 5.6 & GN & 3 & 3.9 & ZM & $67,062,180$ & 8.8 \\
\hline TZ & 14 & 4.1 & $\mathrm{NE} / \mathrm{ZW}$ & 5 & 3.5 & $\mathrm{CG} / \mathrm{ML}$ & 5 & 4.7 & $\mathrm{RW} / \mathrm{SL} / \mathrm{SD} / \mathrm{TZ} / \mathrm{ZM}$ & 3 & 3.9 & $\mathrm{AO}$ & $33,960,276$ & 4.4 \\
\hline & & & & & Cour & y names & re expres & ed a & 2 letters ISO code & & & & & \\
\hline
\end{tabular}

Table 2: Top 5 recipient countries by project type and amount

Regarding the total number of health projects, Uganda is the main recipient with 17 projects, which represents $4.9 \%$ of the total number of health aid projects financed by China in Africa between 2006 and 2013. Over the 2006-2013 period, Tanzania and Zambia are the countries that benefited from the highest number of Chinese medical teams with 9 and 8 teams respectively. Liberia, Uganda and Niger were the main recipients of medical equipment or drugs projects with a total of 9 projects between 2006 and 2013. Regarding infrastructure projects, Central African Republic and Kenya received 4 infrastructure projects while the Republic of Congo, Ghana, Rwanda, Sierra Leone, Tanzania and Zambia benefitted from 3 infrastructure projects. For the 2006-2013 period, Kenya is the country that received the highest amount of health ODA funding with US\$147 million (2014 US\$). Niger, ranks as the second highest recipient country in terms of ODA amount with US\$142 million. Ivory Coast ranks as the third highest recipient countries in terms of health ODA amount with US\$106 million. These three highest recipient countries concentrated more than half (51.8\%) of Chinese health ODA funding between 2006 and 2013.

\subsection{Explanatory variables}

We consider the role of three kinds of variables that might influence the allocation of Chinese health ODA: variables related to the needs and merits of African countries and variables measuring China's own interest.

For the "needs" variables we differentiate between economic and health needs. We use the Gross Domestic Product (GDP) per capita measured in thousands of constant 2011 US\$ (World Bank data) to measure economic needs. If China allocates its health ODA based on the economic needs of beneficiary countries, we should find a negative correlation between the GDP per capita and health aid. We integrate two measures of health needs in the main analysis: public health expenditures as a percentage of $\mathrm{GDP}^{7}$ (World Bank data) and life expectancy at birth (World Bank data). We expect to find a negative correlation between public health expenditures of recipient countries and Chinese health aid if China favors countries where the ability to finance health projects on national funds is limited. If China allocates its health ODA based on health needs of recipient countries we should also find a negative correlation between Chinese health aid and life expectancy in recipient countries. In robustness checks, we also test for the impact

\footnotetext{
${ }^{7}$ Introduced in percentage of GDP given the high correlation of public health expenditures in level with GDP per capita
} 
of under-5 child mortality (per 1000 live births, World Bank data), maternal mortality (per 100,000 live births, World Bank data), malaria confirmed cases (Global Health Observatory data repository of the World Health Organization) and HIV incidence (UNAIDS data), instead of life expectancy, on Chinese heath aid allocation. Finally, we also include the population size as a measure of recipient countries' needs (World Bank data).

To measure recipient countries' merits we introduce one of the Worldwide Governance Indicators (WGIs) used in the literature to reflect the quality of political governance: the control of corruption index (Kaufmann et al., 2011) (World Bank data). The control of corruption index is measured on a scale from -2.5 to 2.5 where a score of 2.5 represents the highest level of corruption control and would therefore be attributed to the least corrupt countries. If Beijing truly applies a non-interference principle for the allocation of its ODA, there should be no significant correlation between the control of corruption index and Chinese health ODA. In robustness analysis, we test the impact of an alternative measure of corruption, the corruption perception index (Transparency International). Indeed, a body of the literature has criticized the use of the WGIs. Critics have focused on problems of biases in the individual indicators that are thought to be influenced by one's country level of development (Knack, 2006). Moreover, several authors consider that the aggregation methodology of the indicators makes the governance quality hard to compare over time and across countries (Kurtz and Shrank, 2007). More importantly, concerns have been raised about the construct validity of these indicators (Thomas, 2010) and their ability to measure distinct concepts of governance (Langbein and Knack, 2010). Still in robustness checks, we also use alternative measures of political governance ${ }^{8}$ such as the polity score (Marshall and Jaggers, 2016), which measures the level of democracy of recipient countries, and three other measures of the WGIs (Kaufmann et al., 2011): the voice and accountability, the regulatory quality and the rule of law indexes.

Variables related to China's own interest can be classified into two categories, economic and political variables. For economic self-interest we first introduce one measure related to the natural resources endowment of African countries: the natural resources rent ${ }^{9}$ as percentage of GDP which is the sum of oil rent, natural gas rent, coal rent, forest rent and mineral rent (World Bank data). If China uses its health aid in order to promote its access to natural resources, a positive correlation should be found between the natural resources rent and health ODA from China. In robustness analysis, we also test for the impact of energy (fuels, minerals and metals) exports of African countries to China (measured in millions of US\$, WITS database), instead of the natural resources rent. The second economic self-interest variable aims to measure the commercial integration of African countries with China. To that end, we introduce the openness rate of recipient countries to $\mathrm{China}^{10}$ (in \% of GDP, WITS and World Bank data) as an

\footnotetext{
${ }^{8}$ All measures of governance are not used in the baseline specification given the high collinearity between these measures.
${ }^{9}$ Natural resources rents are calculated as the difference between the price of the commodity and the average cost of producing it. Unit rents are then multiplied by the physical quantities countries extract to determine the rents for each commodity as a share of GDP.

${ }^{10}$ Exports of China to recipient countries plus exports of recipient countries to China as a percentage of recipient countries' GDP.
} 
explanatory variable. If China uses its health aid to reward or support the opening of domestic markets in African countries, a positive correlation should be found between the openness rate to China and health ODA from China. In robustness analysis, we also test whether imports of recipient countries from China or exports of recipient countries to China, both as percentages of recipient countries' GDP, also influence Chinese health aid allocation. Given a high number of missing values, the amount of Foreign Direct Investment (FDI) received from China by African countries (millions of US\$, UNCTAD FDI/TNC database) is only used as an independent variable in robustness analysis.

To measure Chinese political interests we first calculate UNGA voting alignment of recipient countries with China (in percentage) based on data of Voeten and Merdzanovic (2009). We also include a binary variable for the recognition of Taiwan. A positive correlation between voting alignment with China and health aid and a negative correlation between Taiwan recognition and health aid are expected if China uses its health ODA as part of its diplomatic policy.

Beyond needs, merits and self-interest variables, other explanatory variables are also used in the empirical analysis. We insert the amount of health ODA commitments from DAC countries ${ }^{11}$ (millions of 2015 US\$, OECD) as an explanatory variable to test whether Chinese health ODA can be seen as a way of competition with OECD countries in Africa. We also include the number of ODA projects received from China in various sectors as control variables since ODA projects in different sectors can be tied. We are particularly interested in the complementarity or substitutability between Chinese health aid and Chinese ODA in the related sectors of water supply and sanitation and emergency response.

\section{Methods}

In a first step we study the number of health ODA projects allocated by China to the different African countries. We stratify the analysis by project type of projects and distinguish between medical team dispatches and projects related to the construction of health infrastructures or the sending of medical equipment and drugs. In a second step we study the amount of health ODA received by African countries from China. We set the amount of Chinese health ODA to 0 if a country received no Chinese health ODA project in a given year. For each country-year, ODA amounts are coded as missing if financial valorization lacks for all projects received.

Given the important share of countries that benefit from no Chinese health ODA project or amount each year, simple regression techniques such as Ordinary Least Square (OLS) cannot be used to estimate the factors associated with Chinese health ODA allocation. Indeed, in the presence of many zero observations, OLS estimates would be biased toward 0 . To correct this bias, several types of econometric models are available. First, a Two-Part model can be used in order to estimate independently the factors associated with the reception of a positive value of Chinese health ODA and the factors associated with the aid volume among recipient countries.

\footnotetext{
${ }^{11}$ DAC countries health aid commitments, rather than disbursements, are used given the high number of missing values for disbursements over the study period.
} 
However, such model suffers from the risk of introducing a selection bias in the second step if the selection as a recipient by China is not independent of the volume of Chinese health aid received. The Heckman selection model allows correcting this selection bias at the cost of introducing an exclusion restriction which imposes that at least one independent variable must explain the selection process but not the volume of Chinese health aid received among recipient countries. Two-Part and Heckman selection models would assume that Chinese aid allocation decisions are made sequentially by deciding first which countries will benefit from health aid and then choosing the volume of health aid to allocate to these countries. This would imply a high centralization or coordination in Chinese aid policy while the literature has shown that Chinese aid allocation decisions involve multiple actors at the national and regional levels (Grépin et al., 2014; Lin et al., 2016). Even though a large part of Chinese health aid is managed by the Ministry of Commerce and by the National Health and Family Planning Commission ${ }^{12}$, the implementation of bilateral agreements with African countries often rests on Chinese provincial authorities. For example, provincial Chinese governments are in charge of the sending of medical teams to African countries. Given the fragmented process of decision in Chinese aid allocation policy, we choose not to use Two-Part and Heckman selection models in the main analysis. Nevertheless, we provide the results of the Heckman selection models, using the recognition of Taiwan as the exclusion restriction, in Appendix A. Results of regressions using Heckman selection models are similar to those of our preferred specification. However, for all dependent variables, the likelihood ratio test of independent equations indicates that the Heckman selection model does not perform better than a simple OLS regression.

A third solution for dealing with the overrepresentation of 0 would be to use a Tobit model which estimates the factors associated with the volume of health aid in one step while correcting for the downward bias introduced by the many 0 observations. Despite its appeal, the Tobit model imposes a homoscedasticity condition on residuals and produces biased estimates in the presence of heteroscedasticity.

We choose then to use maximum likelihood Poisson regressions in order to study the factors associated with Chinese health ODA projects and amounts by country-year. Poisson regressions are suitable for count data such as the number of projects ${ }^{13}$. Regarding the use of Poisson regressions for the estimation of health ODA amount received, Silva and Tenreyro (2006 and 2011) have demonstrated that Poisson models outperform Tobit models in the presence of heteroskedasticity and many zero observations. Poisson models are being increasingly used in the trade literature for the estimation of gravity models of bilateral trade (Fernandes et al., 2016; Anderson et Yotov, 2016). Moreover, recent studies have also used Poisson models to estimate ODA amounts received from DAC countries (Acht et al., 2015).

\footnotetext{
${ }^{12}$ The Chinese Ministry of Health. It has a department devoted to international cooperation.

13 The regressions for the number of projects stratified by type were also run using ordered logit regressions. All results are robust to the use of this alternative econometric specification. Results of these alternative regression analyses are available in Table B1 in Appendix B.
} 
Given large year-to-year variations in the number and amount of health ODA projects allocated by China to African countries, we follow Dollar and Levin (2006), Younas (2008) and Nunnenkamp and Öhler (2011), and we pool data from 2006 to 2013 while including year dummies in regressions. Pooled regressions were favored compared to fixed effect models, given the low time variability of some explanatory variables (for example the recognition of Taiwan or the control of corruption index). This allows us to exploit both inter and intra-country heterogeneity to analyze the factors associated with Chinese health aid. As a robustness analysis, we also run random effects regressions. Random effects models control for recipient-specific characteristics and allow measuring the effect of variables that exhibit little variation over time. Results of random effects Poisson regressions are presented in Appendix C. For the number of projects (total number of projects, medical teams, infrastructure and medical equipment/drugs projects), results are very close to those obtained using pooled regressions. Moreover, the likelihood ratio tests indicate that random-effects models are not significantly different from pooled models for all types of health projects. However, the result of the likelihood ratio test favors the use of the random effects model for the amount of health ODA. In the results section, and for all robustness analyses, we then present the regressions results of both pooled and random effects models for health ODA amount.

All regressions were run using robust standard errors clustered at the country level. Except for the number of non-health ODA projects from China or heath aid commitment from DAC countries (for which simultaneity with Chinese health ODA is of interest) all explanatory variables are lagged to mitigate concerns of reverse causality. To limit the multicolinearity issue, GDP per capita and public health expenditures as percentage of GDP were centered. The results of multicolinearity diagnostic tests show that multicolinearity is not an issue. Results are reported as incidence rate ratios (IRR) in order to quantify the impact of explanatory variables on the number of health projects and the amount of health ODA received.

All regression analyses were also run using the share of health projects and the share of health ODA amount received by African countries each year. These regression analyses were run using the fractional probit method developed by Papke and Wooldridge (1996) for the case of proportions as dependent variables. Again, all regressions include year fixed effects, were run using robust standard errors clustered at the country level and all explanatory variables were lagged to mitigate concerns of reverse causality (except for non-health ODA projects received from China and the amount of heath aid commitment of DAC countries).

\section{Results}

\subsection{Descriptive statistics}

Table 3 displays the descriptive statistics of the dependent and independent variables for the sample used in the main regression analysis. 


\begin{tabular}{|c|c|c|c|c|c|}
\hline Variable & Obs. & Mean & Std. Dev. & Min & Max \\
\hline \multicolumn{6}{|c|}{ Dependent variables } \\
\hline Total number of health ODA projects & 389 & .8303342 & .9775865 & 0 & 4 \\
\hline Number of medical teams & 389 & .3521851 & .5294196 & 0 & 2 \\
\hline Number of infrastructure / drug or equipment projects & 389 & .4318766 & .7097348 & 0 & 4 \\
\hline Health ODA amount (2014 US\$) & 268 & 2803049 & $1.39 \mathrm{e}+07$ & 0 & $1.42 \mathrm{e}+08$ \\
\hline \multicolumn{6}{|c|}{ Independent variables } \\
\hline GDP per capita (constant 2011 US\$) & 389 & 4761.001 & 6076.38 & 5354.237 & 40283.7 \\
\hline Public health expenditures (\% of GDP) & 389 & 2.7427 & 1.355889 & .3684264 & 9.087436 \\
\hline Life expectancy & 389 & 58.11697 & 7.645119 & 41.75961 & 74.60244 \\
\hline Population (million) & 389 & 19.47272 & 27.58999 & .0829 & 168.2404 \\
\hline Control of corruption index & 389 & -.5792601 & .5472603 & -1.545583 & 1.139363 \\
\hline Natural resources rent (\% of GDP) & 389 & 16.93442 & 17.09374 & .0037578 & 80.71241 \\
\hline Openness rate to China (\% GDP) & 389 & 2.593928 & 7.32617 & .0559201 & 83.77744 \\
\hline UNGA voting alignment with China (\%) & 389 & 71.45102 & 19.57258 & 1.538462 & 93.93939 \\
\hline Recognition of Taiwan (\%) & 389 & & & & \\
\hline No & & 91 & & & \\
\hline Yes & & 9 & & & \\
\hline Health ODA commitments DAC (2015 US\$ million) & 389 & 35.11157 & 50.63792 & .000016 & 354.5208 \\
\hline Emergency response ODA projects & 389 & .0642674 & .2657091 & 0 & 2 \\
\hline Water supply and sanitation ODA projects & 389 & .0462725 & .2335688 & 0 & 2 \\
\hline Agriculture, forestry and fishing ODA projects & 389 & .1928021 & .4883695 & 0 & 3 \\
\hline Communications ODA projects & 389 & .092545 & .3316173 & 0 & 2 \\
\hline Debt release projects & 389 & .0796915 & .2983182 & 0 & 2 \\
\hline Education ODA projects & 389 & .344473 & 6498228 & 0 & 4 \\
\hline Energy generation and supply ODA projects & 389 & .0719794 & .2779925 & 0 & 2 \\
\hline Government and civil society ODA projects & 389 & .277635 & .5964142 & 0 & 4 \\
\hline Industry, mining, construction ODA projects & 389 & .0462725 & .2103452 & 0 & 1 \\
\hline Multi-sector ODA projects & 389 & .0874036 & .3004648 & 0 & 2 \\
\hline Other social infrastructure and services ODA projects & 389 & .1131105 & .355455 & 0 & 2 \\
\hline Transport and storage ODA projects & 389 & .1722365 & .4747765 & 0 & 3 \\
\hline
\end{tabular}

Table 3: Descriptive statistics for the sample used in the main regression analysis

The mean number of health ODA projects received by African countries each year over the 20062013 period is equal to 0.83 with a minimum of 0 and a maximum of 4 . The maximum number of medical teams received by an African country in a given year is 2 while the maximum number of the infrastructure and medical equipment/drugs projects is 4 . The mean amount of health ODA received by African countries each year between 2006 and 2013 is US\$2.8 million (2014 US\$) with a maximum of US\$142 million for Niger in 2013. The mean GDP per capita among African countries over the 2005-2012 period is 4761 US\$ (2011 US\$) while mean life expectancy is low and equal to 58.12. In average, African countries spent $2.74 \%$ of their GDP for public health expenditures. Mean population in African countries was 19.47 million in the 2005-2012 period. The mean value of the control of corruption index is equal to -0.58 indicating a high level of corruption among African countries over the study period. In average, revenues from natural resources and trade with China represented respectively $16.93 \%$ and $2.59 \%$ of African countries' 
GDPs between 2005 and 2012. Few countries chose to maintain political relationship with Taiwan in the 2005-2012 period (9\% of country-year observations). Voting alignment of African countries with China is high and equal to $71.45 \%$ on average. Annual health ODA commitments from DAC countries to African countries averaged US\$35.11 million (2015 US\$) in the 20062013 period.

\subsection{Number of health projects and ODA amounts}

Table 4 presents the results of regression analyses for the number of health projects and the amount of health ODA received from China.

\section{Needs}

Regarding the economic needs variable, the GDP per capita is negatively correlated with the total number of projects received which means that the poorer African countries generally tend to benefit from a higher number of projects. A thousand dollar increase in GDP per capita is associated with a 5.5\% decrease in the number of health projects received from China over the 2006-2013 period. The GDP per capita is also negatively correlated with the number of medical teams and the number of infrastructure and medical equipment/drugs projects. However, it is not significantly correlated with the amount of health ODA received from China in pooled regressions and positively correlated with health ODA amount in random effects regressions.

Turning to the health needs variables, results of regression analyses show a negative correlation between public health expenditures as a share of GDP in recipient countries and the total number of health projects, the number of infrastructure and medical equipment/drugs projects and the amount of health ODA received from China but not the number of medical. Over the 2006-2013 period, a one percentage point increase in public health expenditures (as a share of GDP) in recipient countries is associated with decreases of $12.3 \%$ and $15.3 \%$ in the total number of projects and the number of infrastructure and medical equipment/drugs projects financed by China respectively. This effect is even stronger for the amount of health ODA received. Indeed, a one percentage point increase in public health expenditures is associated with a $48.8 \%$ (pooled model) to $92.8 \%$ (random effects model) decrease in the amount of health ODA received from China. Life expectancy is not significantly correlated with either measure of Chinese health ODA project received between 2006 and 2013. However, life expectancy is negatively correlated with the amount of health ODA when considering the pooled model while it is positively correlated with health ODA amount in the random effects model.

As robustness checks we also test whether child mortality, maternal mortality, the number of malaria cases and HIV incidence are associated with Chinese health aid allocation. To do so, we consecutively replace life expectancy by one of these variables in the regression analysis (results shown in Tables D1 to D4 in Appendix D). We again find no association between these alternative measures of health needs and the number of Chinese health ODA project received except for a marginally significant, as well as very small, positive correlation between the number of malaria cases and the total number of health ODA projects received from China. 
Moreover, the association found between life expectancy in African countries and the amount of Chinese health ODA is not confirmed, for both the pooled and the random effects models, when using alternative indicators of health needs such as child mortality, maternal mortality or malaria cases.

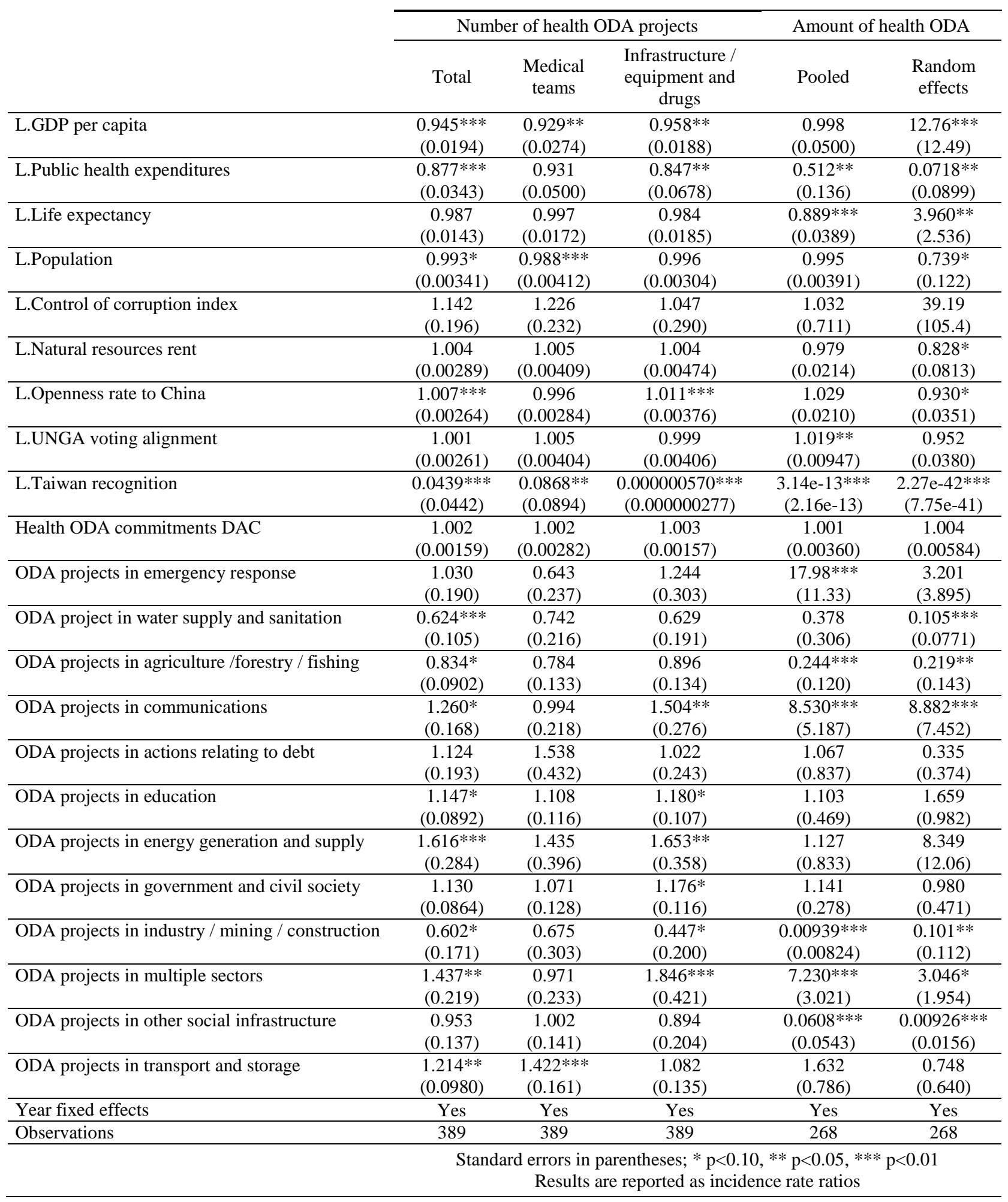

Table 4: Results of regression analyses for the number of projects and the amount received 
China does not appear to disfavor more corrupt countries over the 2006-2013 period. Indeed, no significant correlations are found between the control of corruption index in African countries and neither measure of health ODA from China. This result is confirmed in robustness analysis where we use the corruption perception index as an alternative measure of corruption (results shown in Table E1 in Appendix E). Regarding the alternative measures of governance, we again find no significant association between the voice and accountability, the regulatory quality or the rule of law indexes and the number of health ODA projects received from China. Results of robustness analyses only point to a positive correlation between the voice and accountability index and the amount of health ODA (results shown in Table E2 and E4 in Appendix E). Regarding the last governance indicator, we again find no significant correlation between the polity score and any measure of Chinese health ODA projects. However, we find a positive correlation between this variable and the amount of health ODA (results in Table E5 in Appendix E).

\section{Chinese interests}

For the economic interest variables, the openness rate to China is positively correlated with the total number of projects received and the number of infrastructure and medical equipment/drugs projects. However, the magnitude of these correlations appears low. Over the 2006-2013 period, a one percentage point increase in the openness rate to China is only associated with a $0.7 \%$ increase in the number of health projects received and a $1.1 \%$ increase in the receipt of infrastructure and medical equipment/drugs projects. Moreover, we find a negative correlation between the openness rate to China and the amount of health ODA in random effects regressions, though only significant at the $10 \%$ level. To better understand the link between trade with China and Chinese health aid, we decompose the openness rate between imports from China and exports to China in Tables F1 and F2 in Appendix F. The positive correlations observed between the openness rate to China and the total number of Chinese health ODA projects or the number of infrastructure and medical equipment/drugs projects is driven by the volume of imports of African countries from China. Indeed, we find positive correlations between total Chinese ODA projects or infrastructure and medical equipment/drugs projects and the imports of recipient countries from China as a percentage of their GDP. On the other hand, our results show no significant association between the exports of recipient countries to China as a percentage of their GDP and the total number of Chinese ODA projects or the number of infrastructure and medical equipment/drugs projects. Moreover, the lack of association between the openness rate to China and the number of medical teams received by African countries is explained by opposite correlations found for imports from China and exports to China. While the number of medical teams is negatively correlated with imports from China as a percentage of recipient countries' GDP, it is positively correlated with exports of African countries to China as a percentage of their GDP. Finally, the negative correlation found in the random effects model between the openness rate to China and the amount of health ODA is explained by a negative association between the latter variable and recipient countries' imports from China as a share of their GDP. In robustness analysis, we find no significant correlations between the amount of FDI received 
from China and the volume of Chinese health ODA (results shown in Table F3 Appendix F). We find no evidence that China favors countries with high endowments of natural resources in its health aid allocation. Indeed, results of regression analyses show no significant correlation between the natural resources rent in African countries and the volume of Chinese health ODA received in terms of number of projects. For the amount of health ODA, results of random effects regressions also confirm that countries with more natural resources do not receive more health aid from China. Indeed, the natural resources rent is negatively correlated with the amount of Chinese health ODA. These results are broadly confirmed in robustness analysis by the use of energy exports of African countries to China as an alternative measure of natural resources endowment (results shown in Table F4 in Appendix F). We find no significant correlation between energy exports of African countries to China and the number of Chinese health ODA projects of either type received. We only find positive, and of very low magnitude, correlations between energy exports to China and the amount of health ODA received in both pooled and random effects models (a one million US\$ increase in energy exports to China is associated to $0.0063 \%$ and $0.483 \%$ increases in the amount of health ODA received from China in the pooled and random effects models respectively).

Some political considerations appear to play an important role in Chinese health aid allocation decisions. Over the 2006-2013 period, the recognition of Taiwan by an African country almost systematically excludes it from Chinese health aid programs. This result is coherent with 2006 Beijing Declaration of the third FOCAC that called for an African commitment to the "oneChina" policy. We find no evidence that countries who adopted UNGA voting patterns similar to China were favored by China for the receipt of health aid projects between 2006 and 2013. However, we find a significant and positive correlation between the voting alignment variable and the amount of Chinese health aid in pooled regressions, but not in random effects regressions. According to the pooled regression results, a one percentage point increase in UNGA voting alignment with China is associated with a $1.9 \%$ increase in the amount of Chinese health ODA received over the study period.

The allocation of Chinese health aid in African countries appears unrelated to health aid provided by traditional bilateral donors. Indeed, we find no significant correlations between health ODA commitments of DAC donors and the number of health aid projects or the amount of health ODA received by African countries from China. The empirical analysis also highlights the substitutability of Chinese health ODA with ODA in the sector of water supply and sanitation. Indeed, the number of water supply and sanitation ODA projects is negatively correlated with the number of health ODA projects and the amount of health ODA in the random effects model.

\subsection{Testing robustness of the results: Share of Chinese health aid}

Table 5 presents the results of the regression analyses for the share of health projects and the share of health ODA amount received by African countries from China. For the total number of projects, the number of medical teams and the number of infrastructure and medical equipment/drugs projects, results using the share of Chinese health projects received are very 
similar to those obtained when studying the number of health aid projects. Results similarity tends to indicate that factors associated with health ODA project allocation are the same than those associated with Chinese trade-off of health aid project allocation between African countries.

Regarding the economic needs variable, results are very similar to those obtained in the previous analysis. GDP per capita is negatively correlated with the shares of total health projects, medical teams and infrastructure and medical equipment/drugs projects. However, while we found no correlation (pooled model) or a positive correlation (random effects model) between the GDP per capita and the amount of Chinese health aid received, we now find a negative correlation between the economic needs variable and the share of Chinese health aid amount received.

For health needs variables, we find that public health expenditures as a share of GDP are negatively correlated with the shares of total health projects and health ODA amounts but are not significantly associated with the share of medical teams. In contrast with the previous analysis, we do not find a significant correlation between public health expenditures and the share of infrastructure and medical equipment or drugs projects. Again, we find no significant correlation between life expectancy and the shares of either type of projects received. Moreover, life expectancy is no longer significantly correlated with the amount of Chinese health ODA when using the share of ODA amount.

Turning to the merits variable, we find again no link between the control of corruption index and the receipt of Chinese health ODA either in terms of projects or in terms of amount. Indeed, we find no significant correlation between the control of corruption index and the shares of Chinese health aid received over the study period.

Regarding the economic interest variables, the results for the openness rate to China are similar to those obtained in the previous analysis. Indeed, the openness rate to China is positively correlated with the share of total health projects and the share of infrastructure and medical equipment/drugs projects but is uncorrelated with the share of medical teams. Once again, the significant correlations are of very low magnitude. For the amount of health ODA, we now find a significant and positive correlation between the openness rate to China and the share of Chinese health ODA amount received while this association was insignificant (pooled model) or negative (random effects model) when using the absolute amount of Chinese health aid. These new specifications also confirm that natural resources endowment of African countries does not play a major role in Chinese health aid allocation. Indeed, the natural resources rent is not significantly associated with the shares of medical teams, infrastructure and medical equipment/drugs projects and health ODA amount received. However, while the natural resources rent in African countries was unrelated with the total number of health ODA projects received, we now find that natural resources endowment is positively correlated with the share of total health aid projects received. 


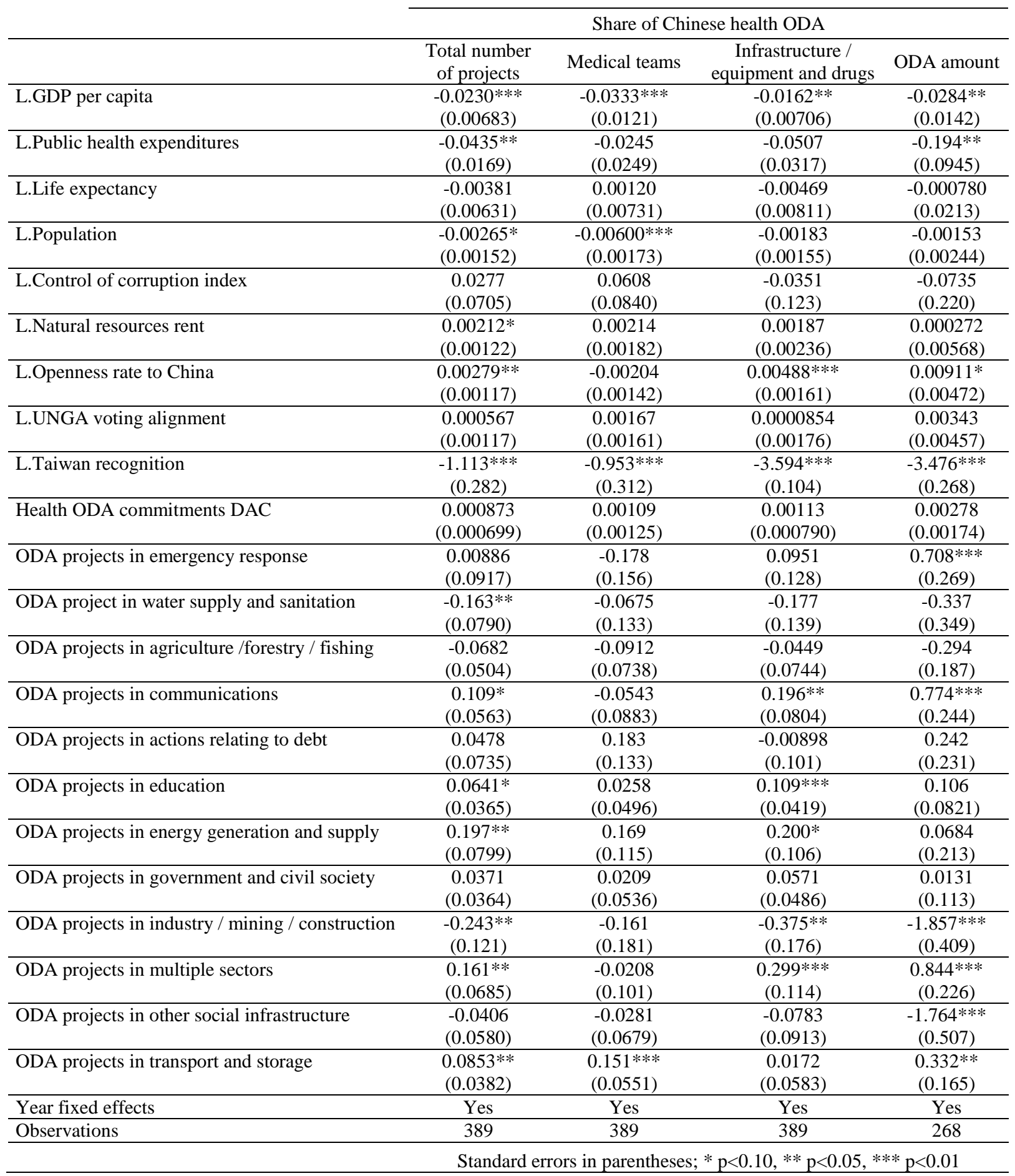

Table 5: Results of regressions analyses for the share of health aid received

We find no difference in the effect of Taiwan recognition between our first analysis and the analysis of the share of health aid received. Taiwan recognition is associated with a strong reduction in the share of health aid projects and the share of health ODA amount received by African countries over the study period. Regarding UNGA voting alignment of African countries with China, results are very similar to those obtained in the previous analysis as results show no significant correlations between UNGA voting alignment and the shares of Chinese health ODA 
projects received. For the amount of health ODA, we find no association between UNGA voting alignment and the share of Chinese health ODA amount received while we previously found a positive correlation between UNGA voting alignment and the amount of health ODA received in the pooled model.

Regarding the relationship between health aid of China and DAC countries, we again find no significant relationship between health ODA commitments of DAC countries in African countries and the share of Chinese health ODA they receive. These new specifications also confirm the substitutability between water supply and sanitation and health ODA projects from China.

\section{Discussion}

Over the 2006-2013 period several general patterns of the Chinese aid allocation can be drawn from our results.

\section{Needs}

Globally, China allocated more health aid to poorer countries over the study period. Chinese health aid was also directed to African countries with higher health financing needs as measured by the share of GDP that is devoted to public health expenditures, health currently being (and likely being for the coming years), drastically underfinanced (Dieleman et al., 2016). This indicates that Chinese health aid favored countries where the ability to finance health policy on national funds was limited. However, over the study period, Chinese health ODA appears unresponsive to more direct measures of health needs in African countries such as life expectancy, child and maternal mortality, malaria prevalence or HIV incidence. These results are coherent with those of Dreher and Fuchs (2015) who find that the sending of Chinese medical teams to all recipient countries over the 1990-1995 period is negatively correlated with their GDP per capita but does not react to their health needs as measured by the total number of people affected by a natural disaster. Dreher et al. (2018) also find that GDP per capita in African countries is negatively correlated with the total amount of all-sectors ODA they receive from China. Our results confirm this pattern in the health sector for all types of health projects.

\section{Merits}

Our results show that, in the allocation of its health aid over the 2006-2013 period, China did not disfavor countries where the corruption was higher. This result is robust to the use of two different measures of corruption, the control of corruption index and the corruption perception index. This result is likely to reflect the non-interference principle that Beijing states to apply in its foreign policy relationships. In robustness analysis, we used alternative measures of governance (the voice and accountability, the regulatory quality and the rule of law indexes as well as the polity score) and find again no association between these governance indicators and the volume of Chinese health ODA received. Our results are coherent with those of Dreher et al. (2018) who find no correlation between the polity score/the control of corruption index and the total amount of all-sectors ODA received by African countries over the 2000-2013 period. 
However, they differ from previous results of Dreher and Fuchs (2015) who find that the sending of Chinese medical teams to all recipient countries was negatively correlated with a dummy variable for democracy over the 1990-1995 period.

\section{Chinese interests}

We find no evidence that Chinese health aid allocation decisions favored African countries with a high level of natural resources over the 2006-2013 period. Indeed, we find no significant correlation between the natural resources rent in African countries and the volume of Chinese health ODA they receive, either in terms of projects number or health ODA amount. When using the share of Chinese health ODA received, we only find a low magnitude correlation between the natural resources rent of African countries and the share of total of health aid projects received. However, this correlation loses statistical significance when disaggregating the analysis by type of projects or when looking at the share of the health ODA amount received. This result contradicts those of Dreher and Fuchs (2015) who find a significant, even though of a small magnitude, correlation between oil production of African countries and the dispatch of medical teams over the 1990-1995 period. Dreher et al. (2018) also find that the total amount of all-sectors Chinese ODA to African countries is independent of oil production in recipient countries over the 2000-20013 period. Our results confirm that natural resources in African countries do not influence Chinese aid allocation decisions in the specific health sector. Still for economic interests, the volume of trade with China appears to be associated with a favorable allocation of Chinese health aid over the 2006-2013 period. Indeed, we find positive and significant - though of low magnitude - correlations between the openness rate to China and the number and share of health aid projects and infrastructure and medical equipment/drugs projects received. While Dreher et al. (2018) find no evidence of a link between commercial ties to China and the total amount of all-sectors ODA received by African countries over the 2000-2013 period, we show the existence of such a link for health aid in terms of number of health aid projects allocated. In robustness analysis we also find that Chinese health aid allocation is not significantly associated with the level of FDI recipient countries received from China.

The allocation of Chinese health aid appears to be strongly linked to some aspects of its foreign policy. African countries which chose to recognize Taiwan were almost entirely excluded from Chinese health aid programs between 2006 and 2013. These results confirm those found by Dreher and Fuchs (2015) and Dreher et al. (2018) for overall Chinese aid allocation to African and non-African countries. Our results show that UNGA voting alignment with China does not influence Chinese health aid received by African countries over the 2006-2013 period. While Dreher and Fuchs (2015) find a positive correlation between UNGA voting alignment and the receipt of Chinese medical teams in all recipient countries over the 1990-1995, we find no such correlation for African countries between 2006 and 2013. Moreover, our results confirm those of Dreher et al. (2018) who find no correlation between UNGA voting alignment and the total amount of all-sectors Chinese ODA received by African countries over the 2000-2013 period. We also find that the allocation of Chinese health aid in African countries is unrelated to health aid provided by traditional bilateral donors, suggesting that health aid cannot be seen as a way for China to promote its international visibility. 
Stuckler and McKee (2008) have described five approaches to global health that may shape the health aid allocation decisions of donor countries. The first approach is global health as foreign policy. In this approach, health aid is used by donor countries for strategic economic and political considerations, for example to forge political alliances or to promote the opening of new trade markets. The second approach is global health as security, where the objective of health aid is to fight communicable diseases that could threaten the population of the donor countries. The third approach is based on charity and focus on the promotion of mother and child health to alleviate poverty. The fourth approach is global health as investment. In this approach, health aid aims to foster economic development in recipient countries through health policies targeted at the working-age population or policies focusing on diseases that slow down economic growth such as HIV/AIDS, malaria or tuberculosis. Finally, the last and fifth approach is global health as public health, where donor countries allocate health aid in order to maximize its health effects and to reduce the global burden of disease. According to our results, the Chinese health aid policy toward African countries mainly follows two of these five approaches; global health as investment and global health as foreign policy. Indeed, China appears to focus its health aid on the most economically disadvantaged countries while we also find evidence that trade and diplomatic ties with African countries influence Chinese health aid allocation decisions. On the other hand, our findings do not provide evidence for the other three approaches of global health described by Stuckler and McKee (2008). In particular, the global health as public health approach does not appear to shape Chinese health aid policy in Africa. Indeed, we find no robust association between various health indicators in African countries (life expectancy, mother and child health, incidence of HIV, malaria and HIV incidence) and the volume of Chinese health aid they receive.

\section{Is Chinese health aid policy less altruistic and more self-interested than DAC donors?}

Chinese health aid policy in Africa is therefore characterized by its focus on the countries that exhibit the highest economic needs, but not necessary the highest health needs, as well as by its strategic commercial and political orientations. However, with regard to the literature on the determinants of traditional donors' health aid allocation decisions, Chinese health aid policy does not appear less altruistic or more self-interested.

Indeed, the literature investigating whether health aid from traditional donors follows the needs of recipient countries has found mixed results. Using aid data from DAC countries to 112 recipient countries between 1995 and 2011, Lee and Lim (2014) find that the value of health aid increases when the health status of a recipient country, as measured by infant mortality, child mortality, or HIV prevalence, deteriorates. On the other hand, Fielding (2011) studies the factors associated with health aid of OECD countries to 109 recipient countries over 1995-2006 and finds that DAC donors' health aid is responsive to child mortality but not to HIV prevalence. Finally, Esser and Bench (2011) study the responsiveness of private foundations' health aid to the needs of 27 low- and middle-income countries in 2005-2007. In their analysis, the disease burden in recipient countries, measured by disability-adjusted life-years, is not associated with public or private aid flows. Regarding the use of health aid as a form of foreign policy, evidence 
of economic self-interest in health aid allocation has also been found for traditional donors such as DAC countries. For example, while Lee and Lim (2004) find that resources-rich and more open countries do not receive more health aid from DAC donors, Fink and Redaelli (2011) show on the contrary that DAC donors favored oil exporting countries for emergency aid over the 1992-2004 period. Political considerations were also found to influence the aid allocation of traditional donors in health-related sectors, even though few articles tested the role of political self-interest in DAC countries' health aid allocation. For example, Fink and Redaelli (2011) show that DAC countries exhibit biases in favor of their former colonies in their emergency aid allocation.

\section{Conclusion}

We study the determinants of Chinese health aid allocation to African countries between 2006 and 2013. Four main takeaways emerge from our results. First, over this period, our results show that Chinese health aid allocation decisions took into consideration the needs of recipient countries. Not only their economic needs, but also and indirectly their health related needs, as we find that Chinese health aid favored countries where the ability to finance health policy on national funds was limited. However, Chinese health ODA allocation decisions appear not to be clearly related to direct measures of health needs in African countries such as life expectancy, child and maternal mortality or malaria and HIV cases. Second, in line with the non-interference principle advocated by China in foreign policy we find that governance of recipient countries does not influence the volume of Chinese health ODA they receive. Third, China is often accused of allocating its ODA to promote its economic development, especially to secure its access to natural resources or favor its exports to emerging markets. Using several measures of natural resources endowment in African countries we find no strong evidence that Chinese health aid allocation decisions favored natural resources-rich countries over the 2006-2013 period. Regarding the link between trade and aid, our results point to an association between the openness rate to China and the volume of Chinese health ODA received. Finally, our results confirm the idea that health aid is used by China as part of its foreign policy. In particular, adherence to the one-China policy appears as a necessary condition for the receipt of Chinese health ODA. 


\section{References}

Acht, M., Mahmoud, T. O., \& Thiele, R. (2015). Corrupt governments do not receive more stateto-state aid: Governance and the delivery of foreign aid through non-state actors. Journal of Development Economics, 114, 20-33.

Anderson, J. E., \& Yotov, Y. V. (2016). Terms of trade and global efficiency effects of free trade agreements, 1990-2002. Journal of International Economics, 99, 279-298.

Dieleman, Joseph L., Tara Templin, Nafis Sadat, Patrick Reidy, Abigail Chapin, Kyle Foreman, Annie Haakenstad, Tim Evans, Christopher JL Murray, et Christoph Kurowski. 2016. « National spending on health by source for 184 countries between 2013 and $2040 »$. The Lancet. Vol. $387.2521-2535$

Dollar, D., \& Levin, V. (2006). The increasing selectivity of foreign aid, 1984-2003. World development, 34(12), 2034-2046.

Dreher, A., \& Fuchs, A. (2015). Rogue aid? An empirical analysis of China's aid allocation. Canadian Journal of Economics/Revue canadienne d'économique, 48(3), 988-1023.

Dreher, A., Fuchs, A., Parks, B., Strange, A. M., \& Tierney, M. J. (2018). Apples and dragon fruits: the determinants of aid and other forms of state financing from China to Africa. International Studies Quarterly, 62(1), 182-194.

Dreher, A., Fuchs, A., Parks, B., Strange, A. M., \& Tierney, M. J. (2017). Aid, China, and Growth: Evidence from a New Global Development Finance Dataset. AidData Working Paper \#46. Williamsburg, VA: AidData.

Esser, D. E., \& Bench, K. K. (2011). Does global health funding respond to recipients' needs? Comparing public and private donors' allocations in 2005-2007. World Development, 39(8), 1271-1280.

Fernandes, A. M., Freund, C., \& Pierola, M. D. (2016). Exporter behavior, country size and stage of development: Evidence from the exporter dynamics database. Journal of Development Economics, 119, 121-137.

Fielding, D. (2011). Health aid and governance in developing countries. Health economics, 20(7), 757-769.

Fink, G., \& Redaelli, S. (2011). Determinants of International Emergency Aid-Humanitarian Need Only?. World Development, 39(5), 741-757. 
Grépin, K. A., Fan, V. Y., Shen, G. C., \& Chen, L. (2014). China's role as a global health donor in Africa: what can we learn from studying under reported resource flows?. Globalization and Health, 10(1), 1.

Kaufmann, D., Kraay, A., \& Mastruzzi, M. (2011). The worldwide governance indicators: methodology and analytical issues. Hague Journal on the Rule of Law, 3(02), 220-246.

Kjøllesdal, K., \& Welle-Strand, A. (2010). Foreign aid strategies: China taking over?. Asian Social Science, 6(10), 3.

Knack, S. (2006). Measuring corruption in Eastern Europe and Central Asia: a critique of the cross-country indicators. The World Bank.

Kurtz, M. J., \& Schrank, A. (2007). Growth and governance: Models, measures, and mechanisms. The Journal of Politics, 69(2), 538-554.

Langbein, L., \& Knack, S. (2010). The worldwide governance indicators: Six, one, or none?. The Journal of Development Studies, 46(2), 350-370.

Lee, S. A., \& Lim, J. Y. (2014). Does international health aid follow recipients' needs? Extensive and intensive margins of health aid allocation. World Development, 64, 104-120.

Lin, S., Gao, L., Reyes, M., Cheng, F., Kaufman, J., \& El-Sadr, W. M. (2016). China's health assistance to Africa: opportunism or altruism?. Globalization and Health, 12(1), 83.

Marshall M and Jaggers K (2016) Polity IV Project: Political regime characteristics and transitions, 1800-2016, dataset users' manual.

Naim, M. (2007). Rogue aid. Foreign policy, (159), 96.

Nunnenkamp, P., \& Öhler, H. (2011). Aid allocation through various official and private channels: Need, merit, and self-interest as motives of German donors. World Development, 39(3), 308-323.

Papke, L. E., \& Wooldridge, J. M. (1996). Econometric methods for fractional response variables with an application to 401 (k) plan participation rates. Journal of Applied Econometrics, 11(6), 619-632.

Silva, J. S., \& Tenreyro, S. (2006). The log of gravity. The Review of Economics and statistics, $88(4), 641-658$.

Silva, J. S., \& Tenreyro, S. (2011). Further simulation evidence on the performance of the Poisson pseudo-maximum likelihood estimator. Economics Letters, 112(2), 220-222.

State Council Information Office (2014), White paper on China's foreign aid, Beijing. 
Stuckler, D., \& McKee, M. (2008). Five metaphors about global-health policy. The Lancet, 372(9633), 95-97.

Thomas, M. A. (2010). What do the worldwide governance indicators measure?. The European Journal of Development Research, 22(1), 31-54.

Voeten, E., \& Merdzanovic, A. (2009). United Nations general assembly voting data. Washington, DC, United States: Georgetown University. http://dvn. iq. harvard. edu/dvn/dv/Voeten/faces/study/StudyPage. xhtml.

Youde, J. (2010). China's health diplomacy in Africa. China: An International Journal, 8(01), 151-163.

Younas, J. (2008). Motivation for bilateral aid allocation: Altruism or trade benefits. European Journal of Political Economy, 24(3), 661-674. 


\section{Appendix A: Result of regression analyses using Heckman selection models}

For convergence issues, only the number of ODA projects in the sectors of emergency response and water supply and sanitation were included as control variables. Results are not presented for the number of infrastructure and medical equipment/drugs projects for which the regression analysis does not converge even after excluding all controls for ODA projects in other sectors and the control for the amount of Health ODA commitments of DAC countries.

\begin{tabular}{|c|c|c|c|c|c|c|}
\hline & \multicolumn{2}{|c|}{$\begin{array}{c}\text { Total number of } \\
\text { projects }\end{array}$} & \multicolumn{2}{|c|}{ Medical teams } & \multicolumn{2}{|c|}{ Amount of health ODA } \\
\hline & Selection & Allocation & Selection & Allocation & Selection & Allocation \\
\hline \multirow[t]{2}{*}{ L.GDP per capita } & $-0.0600 * * *$ & 0.00657 & $-0.0582 * *$ & 0.00362 & -0.0336 & -220199.2 \\
\hline & $(0.0193)$ & $(0.0107)$ & $(0.0230)$ & $(0.00392)$ & $(0.0219)$ & $(356112.1)$ \\
\hline \multirow[t]{2}{*}{ L.Public health expenditures } & -0.0820 & -0.0750 & -0.0393 & $-0.0370 *$ & $-0.189 *$ & -3032034.0 \\
\hline & $(0.0663)$ & $(0.0462)$ & $(0.0635)$ & $(0.0197)$ & $(0.0987)$ & $(2038302.7)$ \\
\hline \multirow[t]{2}{*}{ L.Life expectancy } & -0.00982 & $-0.0207 *$ & -0.00460 & -0.00369 & -0.0173 & -29350.1 \\
\hline & $(0.0123)$ & $(0.0124)$ & $(0.0128)$ & $(0.00501)$ & $(0.0142)$ & (467237.6) \\
\hline \multirow[t]{2}{*}{ L.Population } & $-0.00552 *$ & $-0.00407 * *$ & $-0.0104 * * *$ & -0.000689 & -0.00481 & -69796.0 \\
\hline & $(0.00327)$ & $(0.00201)$ & $(0.00384)$ & $(0.00121)$ & $(0.00392)$ & $(65939.4)$ \\
\hline \multirow[t]{2}{*}{ L.Control of corruption index } & 0.0528 & 0.183 & 0.0969 & 0.0934 & 0.00141 & -1145430.0 \\
\hline & $(0.190)$ & $(0.193)$ & $(0.199)$ & $(0.0789)$ & $(0.256)$ & $(5396862.8)$ \\
\hline \multirow[t]{2}{*}{ L.Natural resources rent } & 0.00144 & 0.00414 & 0.00683 & -0.000638 & -0.000837 & -16916.3 \\
\hline & $(0.00554)$ & $(0.00392)$ & $(0.00526)$ & $(0.00103)$ & $(0.00691)$ & $(131588.4)$ \\
\hline \multirow[t]{2}{*}{ L.Openness rate to China } & $0.0290 *$ & 0.00362 & -0.000315 & -0.00197 & $0.0460 * *$ & -185068.8 \\
\hline & $(0.0152)$ & $(0.00991)$ & $(0.00905)$ & $(0.00124)$ & $(0.0219)$ & $(136921.0)$ \\
\hline \multirow[t]{2}{*}{ L.UNGA voting alignment } & -0.000686 & 0.000946 & 0.00326 & 0.00101 & 0.000246 & 57977.2 \\
\hline & $(0.00387)$ & $(0.00328)$ & $(0.00391)$ & $(0.00117)$ & $(0.00490)$ & $(106469.2)$ \\
\hline \multirow[t]{2}{*}{ L.Taiwan recognition } & $-2.229 * * *$ & & $-1.653 * * *$ & & $-6.051 * * *$ & \\
\hline & $(0.433)$ & & $(0.440)$ & & $(0.277)$ & \\
\hline \multirow[t]{2}{*}{ Health ODA commitments DAC } & 0.00180 & $0.00328 * * *$ & 0.00165 & $0.00180 * *$ & $0.00337 *$ & 15285.6 \\
\hline & $(0.00176)$ & $(0.00111)$ & $(0.00179)$ & $(0.000828)$ & $(0.00203)$ & $(38878.6)$ \\
\hline \multirow[t]{2}{*}{ ODA projects in emergency response } & 0.0314 & -0.108 & -0.320 & -0.0500 & -0.242 & 30369188.6 \\
\hline & $(0.261)$ & $(0.162)$ & $(0.267)$ & $(0.0399)$ & $(0.340)$ & $(22143071.8)$ \\
\hline \multirow[t]{2}{*}{ ODA project in water supply and sanitation } & -0.242 & -0.242 & -0.278 & 0.0790 & -0.269 & -4898623.6 \\
\hline & $(0.295)$ & $(0.237)$ & $(0.304)$ & $(0.183)$ & $(0.326)$ & $(3035743.3)$ \\
\hline Year fixed effects & Yes & Yes & Yes & Yes & Yes & Yes \\
\hline $\mathrm{N}$ & 389 & 204 & 389 & 127 & 268 & 83 \\
\hline Wald test of independent equations $(\mathrm{rho}=0)$ & 1.90 & & 0.53 & & 0.42 & \\
\hline
\end{tabular}

Standard errors in parentheses; $* \mathrm{p}<0.10, * * \mathrm{p}<0.05, * * * \mathrm{p}<0.01$

Table A1: Results of regression analyses using Heckman selection models 


\section{Appendix B: Results of regression analyses using ordered logit models}

\begin{tabular}{|c|c|c|c|}
\hline & \multicolumn{3}{|c|}{ Number of health ODA projects } \\
\hline & Total & Medical teams & $\begin{array}{c}\text { Infrastructure / } \\
\text { equipment and drugs }\end{array}$ \\
\hline \multirow[t]{2}{*}{ L.GDP per capita } & $0.898 * * *$ & $0.900 * *$ & $0.941 * *$ \\
\hline & $(0.0328)$ & $(0.0372)$ & $(0.0260)$ \\
\hline \multirow[t]{2}{*}{ L.Public health expenditures } & $0.783 * * *$ & 0.885 & $0.800^{*}$ \\
\hline & $(0.0600)$ & $(0.0814)$ & $(0.0933)$ \\
\hline \multirow[t]{2}{*}{ L.Life expectancy } & 0.981 & 0.994 & 0.979 \\
\hline & $(0.0270)$ & $(0.0270)$ & $(0.0269)$ \\
\hline \multirow[t]{2}{*}{ L.Population } & $0.988 *$ & $0.981 * * *$ & 0.993 \\
\hline & $(0.00657)$ & $(0.00684)$ & $(0.00489)$ \\
\hline \multirow[t]{2}{*}{ L.Control of corruption index } & 1.127 & 1.308 & 0.962 \\
\hline & $(0.330)$ & $(0.405)$ & $(0.376)$ \\
\hline \multirow{2}{*}{ L.Natural resources rent } & 1.006 & 1.009 & 1.006 \\
\hline & $(0.00658)$ & $(0.00693)$ & $(0.00878)$ \\
\hline \multirow[t]{2}{*}{ L.Openness rate to China } & $1.019 * *$ & 0.995 & $1.021 * * *$ \\
\hline & $(0.00844)$ & $(0.00544)$ & $(0.00681)$ \\
\hline \multirow[t]{2}{*}{ L.UNGA voting alignment } & 1.004 & 1.007 & 0.998 \\
\hline & $(0.00555)$ & $(0.00652)$ & $(0.00656)$ \\
\hline \multirow[t]{2}{*}{ L.Taiwan recognition } & $0.0256 * * *$ & $0.0565 * * *$ & $0.000000396^{* * *}$ \\
\hline & $(0.0253)$ & $(0.0579)$ & $(0.000000208)$ \\
\hline \multirow[t]{2}{*}{ Health ODA commitments DAC } & 1.004 & 1.002 & 1.004 \\
\hline & $(0.00445)$ & $(0.00544)$ & $(0.00314)$ \\
\hline \multirow[t]{2}{*}{ ODA projects in emergency response } & 1.006 & 0.494 & 1.288 \\
\hline & $(0.411)$ & $(0.262)$ & $(0.545)$ \\
\hline \multirow[t]{2}{*}{ ODA project in water supply and sanitation } & $0.317 * * *$ & $0.496^{*}$ & 0.513 \\
\hline & $(0.100)$ & $(0.209)$ & $(0.235)$ \\
\hline \multirow[t]{2}{*}{ ODA projects in agriculture /forestry / fishing } & 0.660 & 0.677 & 0.835 \\
\hline & $(0.174)$ & $(0.179)$ & $(0.227)$ \\
\hline \multirow[t]{2}{*}{ ODA projects in communications } & 1.684 & 0.838 & $2.142 * *$ \\
\hline & $(0.599)$ & $(0.324)$ & $(0.671)$ \\
\hline \multirow[t]{2}{*}{ ODA projects in actions relating to debt } & 1.291 & 2.300 & 0.925 \\
\hline & $(0.453)$ & $(1.228)$ & $(0.413)$ \\
\hline \multirow[t]{2}{*}{ ODA projects in education } & $1.370^{*}$ & 1.189 & $1.371 * *$ \\
\hline & $(0.223)$ & $(0.225)$ & $(0.194)$ \\
\hline \multirow[t]{2}{*}{ ODA projects in energy generation and supply } & $2.805^{* *}$ & 1.967 & $2.292 * *$ \\
\hline & $(1.143)$ & $(0.985)$ & $(0.830)$ \\
\hline \multirow[t]{2}{*}{ ODA projects in government and civil society } & 1.236 & 1.166 & 1.283 \\
\hline & $(0.284)$ & $(0.231)$ & $(0.253)$ \\
\hline \multirow[t]{2}{*}{ ODA projects in industry / mining / construction } & $0.358^{*}$ & 0.521 & $0.277 * *$ \\
\hline & $(0.190)$ & $(0.347)$ & $(0.169)$ \\
\hline \multirow[t]{2}{*}{ ODA projects in multiple sectors } & $2.431 * *$ & 1.070 & $2.591 * *$ \\
\hline & $(0.902)$ & $(0.414)$ & $(1.255)$ \\
\hline \multirow[t]{2}{*}{ ODA projects in other social infrastructure } & 0.835 & 1.099 & 0.767 \\
\hline & $(0.265)$ & $(0.327)$ & $(0.228)$ \\
\hline \multirow[t]{2}{*}{ ODA projects in transport and storage } & $1.663 * *$ & $2.032 * *$ & 1.150 \\
\hline & $(0.363)$ & $(0.567)$ & $(0.244)$ \\
\hline Year fixed effects & Yes & Yes & Yes \\
\hline Observations & 389 & 389 & 389 \\
\hline & Standard errors & $\begin{array}{l}\text { theses; } * p<0.10 \\
\text { re presented as c }\end{array}$ & $\begin{array}{l}{ }^{*} \mathrm{p}<0.05, * * * \mathrm{p}<0.01 \\
\text { ratios }\end{array}$ \\
\hline
\end{tabular}

Table B1: Results of regression analyses using ordered logit models 


\section{Appendix C: Results of regression analyses using Poisson random effects models}

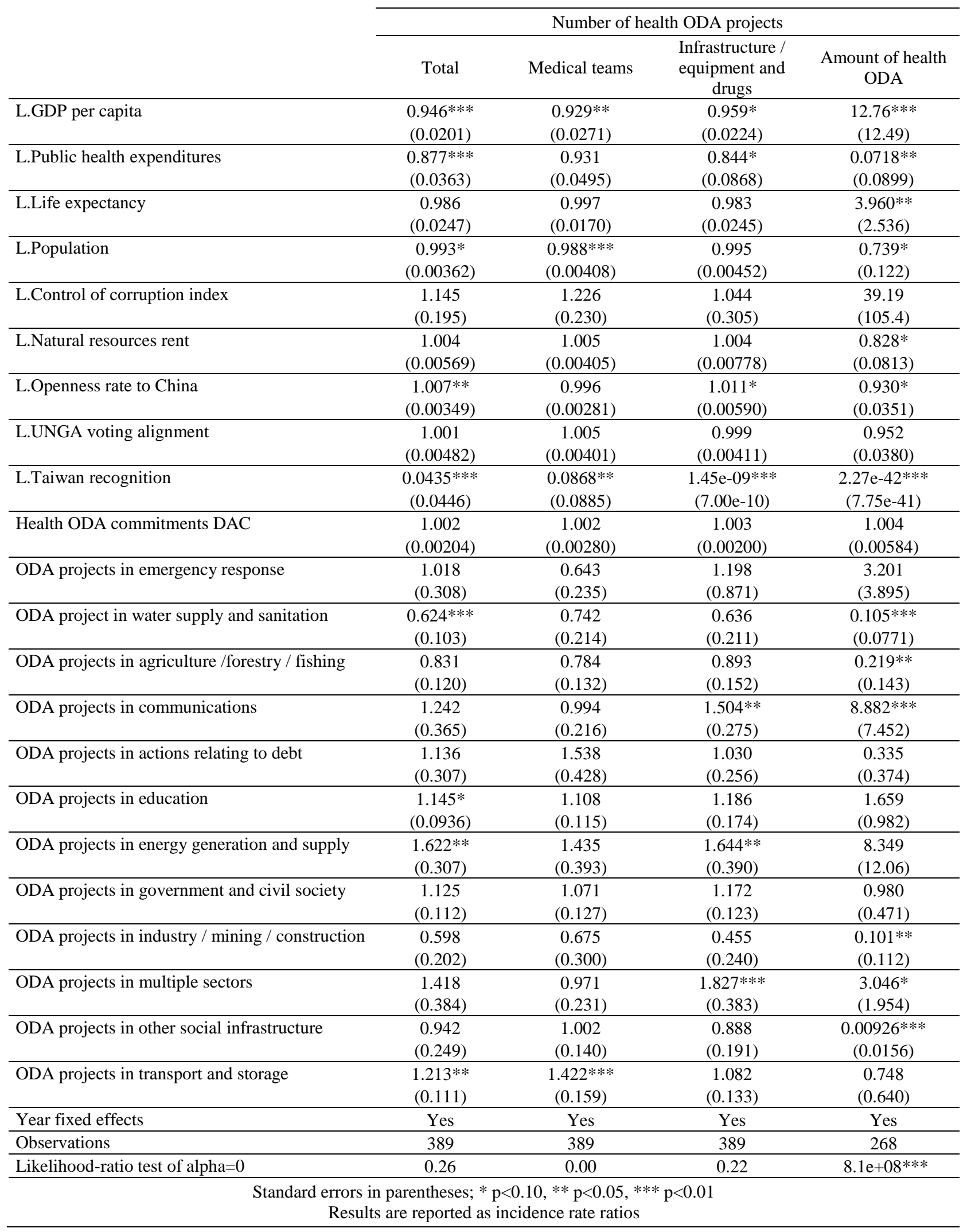

Table C1: Results of regression analyses using Poisson random effects models 


\section{Appendix D: Results of regression analyses using alternative measures of health needs}

\begin{tabular}{|c|c|c|c|c|c|}
\hline & \multirow{2}{*}{\multicolumn{3}{|c|}{ Number of health ODA projects }} & \multirow{2}{*}{\multicolumn{2}{|c|}{ Amount of health ODA }} \\
\hline & & & & & \\
\hline & Total & Medical teams & $\begin{array}{l}\text { Infrastructure } \\
\text { / equipment } \\
\text { and drugs }\end{array}$ & Pooled & $\begin{array}{l}\text { Random } \\
\text { effects }\end{array}$ \\
\hline \multirow[t]{2}{*}{ L.GDP per capita } & $0.945 * * *$ & $0.928 * *$ & $0.962 * *$ & 0.962 & $8.932^{*}$ \\
\hline & $(0.0192)$ & $(0.0270)$ & $(0.0180)$ & $(0.0638)$ & $(11.59)$ \\
\hline \multirow[t]{2}{*}{ L.Public health expenditures } & $0.883 * * *$ & 0.934 & $0.847 * *$ & $0.545 * * *$ & $0.0881 * *$ \\
\hline & $(0.0332)$ & $(0.0455)$ & $(0.0660)$ & $(0.128)$ & $(0.105)$ \\
\hline \multirow[t]{2}{*}{ L.Child mortality } & 1.002 & 1.000 & 1.004 & 1.007 & 0.995 \\
\hline & $(0.00230)$ & $(0.00285)$ & $(0.00323)$ & $(0.00859)$ & $(0.0930)$ \\
\hline \multirow[t]{2}{*}{ L.Population } & $0.993 *$ & $0.988 * * *$ & 0.996 & 0.996 & $0.708^{*}$ \\
\hline & $(0.00350)$ & $(0.00412)$ & $(0.00294)$ & $(0.00494)$ & $(0.144)$ \\
\hline \multirow[t]{2}{*}{ L.Control of corruption index } & 1.110 & 1.207 & 1.053 & 0.629 & 14.16 \\
\hline & $(0.183)$ & $(0.222)$ & $(0.298)$ & $(0.507)$ & $(40.42)$ \\
\hline \multirow[t]{2}{*}{ L.Natural resources rent } & 1.004 & 1.005 & 1.003 & 0.977 & 0.864 \\
\hline & $(0.00321)$ & $(0.00391)$ & $(0.00533)$ & $(0.0265)$ & $(0.0842)$ \\
\hline \multirow[t]{2}{*}{ L.Openness rate to China } & $1.006 * *$ & 0.996 & $1.010^{* * *}$ & 1.024 & 0.956 \\
\hline & $(0.00254)$ & $(0.00280)$ & $(0.00363)$ & $(0.0208)$ & $(0.0875)$ \\
\hline \multirow[t]{2}{*}{ L.UNGA voting alignment } & 1.002 & 1.004 & 1.000 & 1.018 & 0.949 \\
\hline & $(0.00288)$ & $(0.00417)$ & $(0.00415)$ & $(0.0115)$ & $(0.0441)$ \\
\hline \multirow[t]{2}{*}{ L.Taiwan recognition } & $0.0442 * * *$ & $0.0868 * *$ & $4.28 \mathrm{e}-08 * * *$ & $2.69 \mathrm{e}-14 * * *$ & $1.38 \mathrm{e}-41 * * *$ \\
\hline & $(0.0448)$ & $(0.0895)$ & $(2.11 \mathrm{e}-08)$ & $(1.95 \mathrm{e}-14)$ & $(4.57 \mathrm{e}-40)$ \\
\hline \multirow[t]{2}{*}{ Health ODA commitments DAC } & 1.002 & 1.002 & 1.002 & 1.002 & 1.009 \\
\hline & $(0.00158)$ & $(0.00283)$ & $(0.00158)$ & $(0.00373)$ & $(0.00648)$ \\
\hline \multirow[t]{2}{*}{ ODA projects in emergency response } & 1.026 & 0.640 & 1.262 & $14.84 * * *$ & 1.112 \\
\hline & $(0.195)$ & $(0.236)$ & $(0.325)$ & $(9.889)$ & $(1.416)$ \\
\hline \multirow[t]{2}{*}{ ODA project in water supply and sanitation } & $0.625 * * *$ & 0.741 & 0.629 & 0.309 & 0.260 \\
\hline & $(0.105)$ & $(0.215)$ & $(0.193)$ & $(0.261)$ & $(0.223)$ \\
\hline \multirow[t]{2}{*}{ ODA projects in agriculture /forestry / fishing } & 0.842 & 0.784 & 0.912 & $0.285 * *$ & $0.254 * *$ \\
\hline & $(0.0904)$ & $(0.134)$ & $(0.135)$ & $(0.145)$ & $(0.174)$ \\
\hline ODA projects in communications & $1.283^{*}$ & 0.997 & $1.543 * *$ & $6.575 * * *$ & $18.58 * *$ \\
\hline & $(0.169)$ & $(0.211)$ & $(0.293)$ & $(4.310)$ & $(24.32)$ \\
\hline ODA projects in actions relating to debt & 1.113 & 1.538 & 0.997 & 0.967 & 1.614 \\
\hline & $(0.192)$ & $(0.431)$ & $(0.243)$ & $(0.831)$ & $(1.459)$ \\
\hline ODA projects in education & $1.164 *$ & 1.109 & $1.212 * *$ & 1.151 & 1.968 \\
\hline & $(0.0925)$ & $(0.119)$ & $(0.105)$ & $(0.524)$ & $(1.135)$ \\
\hline ODA projects in energy generation and supply & $1.624 * * *$ & 1.439 & $1.661 * *$ & 1.350 & 4.772 \\
\hline & $(0.288)$ & $(0.399)$ & $(0.361)$ & $(0.985)$ & $(5.839)$ \\
\hline ODA projects in government and civil society & $1.134 *$ & 1.073 & $1.180^{*}$ & 1.163 & 1.469 \\
\hline & $(0.0825)$ & $(0.127)$ & $(0.109)$ & $(0.322)$ & $(0.650)$ \\
\hline ODA projects in industry / mining / construction & $0.618 *$ & 0.679 & $0.458^{*}$ & $0.0177 * * *$ & $0.0316^{* * *}$ \\
\hline & $(0.175)$ & $(0.304)$ & $(0.201)$ & $(0.0143)$ & $(0.0334)$ \\
\hline ODA projects in multiple sectors & $1.436 * *$ & 0.969 & $1.859 * * *$ & $6.312 * * *$ & 3.823 \\
\hline & $(0.220)$ & $(0.231)$ & $(0.421)$ & $(3.440)$ & $(3.264)$ \\
\hline ODA projects in other social infrastructure & 0.963 & 1.001 & 0.913 & $0.0506 * * *$ & $0.0168 * *$ \\
\hline & $(0.134)$ & $(0.139)$ & $(0.206)$ & $(0.0550)$ & $(0.0308)$ \\
\hline ODA projects in transport and storage & $1.220 * *$ & $1.421 * * *$ & 1.101 & 1.493 & 0.652 \\
\hline & $(0.103)$ & $(0.162)$ & $(0.143)$ & $(0.670)$ & $(0.626)$ \\
\hline Year fixed effects & Yes & Yes & Yes & Yes & Yes \\
\hline Observations & 389 & 389 & 389 & 268 & 268 \\
\hline & Stan & rd errors in pare & heses; $* \mathrm{p}<0.1$ & $* * \mathrm{p}<0.05, * *$ & $<0.01$ \\
\hline
\end{tabular}

Table D1: Results of regression analyses using child mortality as a measure of health need 


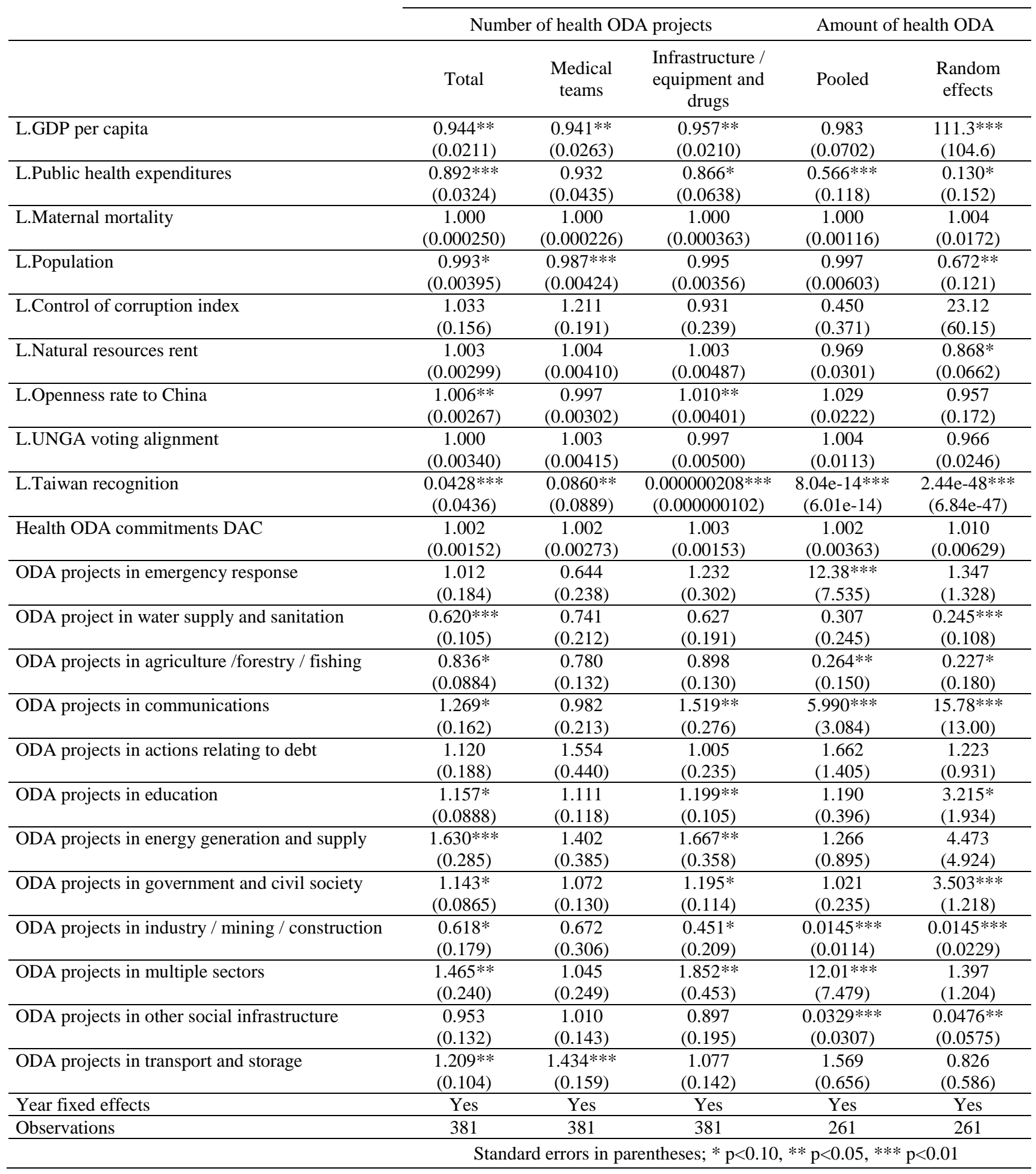

Table D2: Results of regression analyses using maternal mortality as a measure of health need 


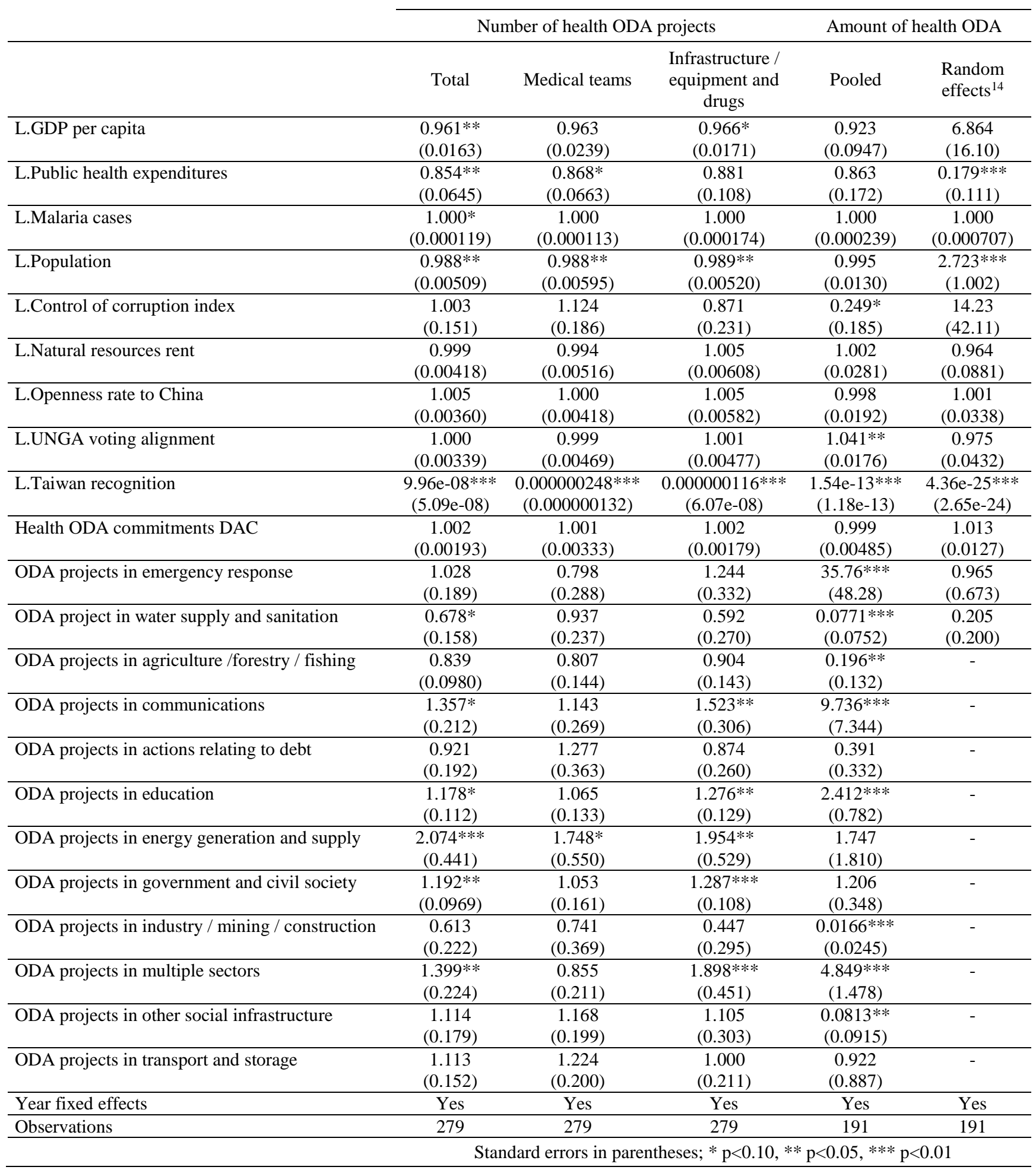

Table D3: Results of regression analyses using malaria cases as a measure of health need

\footnotetext{
${ }^{14}$ For convergence issues only the number of Chinese ODA projects in emergency response and water supply and sanitation were included as control variables.
} 


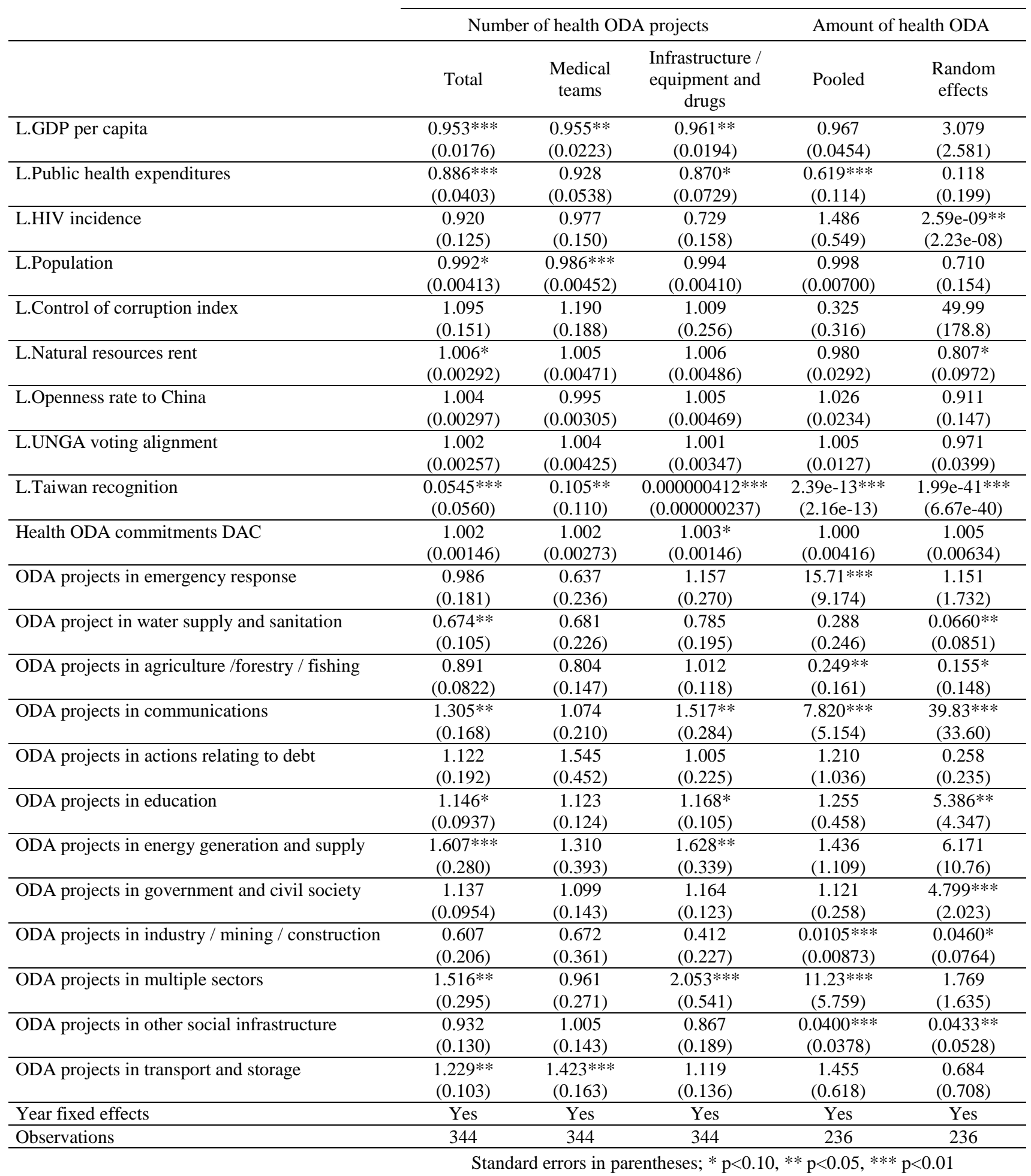

Table D4: Results of regression analyses using HIV incidence as a measure of health need 


\section{Appendix E: Results of regression analyses using alternative measures of merits}

\begin{tabular}{|c|c|c|c|c|c|}
\hline & \multirow{2}{*}{\multicolumn{3}{|c|}{ Number of health ODA projects }} & & \\
\hline & & & & \multicolumn{2}{|c|}{ Amount of health ODA } \\
\hline & Total & $\begin{array}{c}\text { Medical } \\
\text { teams }\end{array}$ & $\begin{array}{c}\text { Infrastructure / } \\
\text { equipment and } \\
\text { drugs }\end{array}$ & Pooled & $\begin{array}{l}\text { Random } \\
\text { effects }\end{array}$ \\
\hline \multirow[t]{2}{*}{ L.GDP per capita } & $0.943 * * *$ & $0.926 * *$ & $0.960 * *$ & 1.016 & $15.83 * *$ \\
\hline & $(0.0202)$ & $(0.0306)$ & $(0.0170)$ & $(0.0543)$ & $(18.83)$ \\
\hline \multirow[t]{2}{*}{ L.Public health expenditures } & $0.880 * * *$ & 0.950 & $0.841 * *$ & $0.574 * *$ & $0.0901 *$ \\
\hline & $(0.0334)$ & $(0.0439)$ & $(0.0620)$ & $(0.144)$ & $(0.129)$ \\
\hline \multirow[t]{2}{*}{ L.Life expectancy } & 0.987 & 1.001 & 0.983 & $0.895 * * *$ & $2.751 *$ \\
\hline & $(0.0140)$ & $(0.0165)$ & $(0.0183)$ & $(0.0370)$ & $(1.550)$ \\
\hline \multirow[t]{2}{*}{ L.Population } & $0.993 *$ & $0.987 * * *$ & 0.995 & 0.995 & $0.731 * *$ \\
\hline & $(0.00349)$ & $(0.00430)$ & $(0.00315)$ & $(0.00465)$ & $(0.0930)$ \\
\hline \multirow[t]{2}{*}{ L.Corruption perception index } & 1.008 & 1.011 & 1.000 & 0.969 & 0.826 \\
\hline & $(0.0112)$ & $(0.0128)$ & $(0.0165)$ & $(0.0464)$ & $(0.104)$ \\
\hline \multirow[t]{2}{*}{ L.Natural resources rent } & 1.004 & 1.005 & 1.003 & 0.973 & $0.880^{*}$ \\
\hline & $(0.00292)$ & $(0.00445)$ & $(0.00457)$ & $(0.0228)$ & $(0.0680)$ \\
\hline \multirow[t]{2}{*}{ L.Openness rate to China } & $1.006 * *$ & 0.995 & $1.010 * *$ & 1.031 & 0.958 \\
\hline & $(0.00257)$ & $(0.00295)$ & $(0.00390)$ & $(0.0218)$ & $(0.0312)$ \\
\hline \multirow[t]{2}{*}{ L.UNGA voting alignment } & 1.001 & 1.004 & 0.998 & $1.020 * *$ & 0.968 \\
\hline & $(0.00268)$ & $(0.00419)$ & $(0.00402)$ & $(0.00962)$ & $(0.0463)$ \\
\hline \multirow[t]{2}{*}{ L.Taiwan recognition } & $0.0446 * * *$ & $0.0860 * *$ & $0.000000570 * * *$ & $2.14 \mathrm{e}-13 * * *$ & $1.13 \mathrm{e}-40 * * *$ \\
\hline & $(0.0451)$ & $(0.0890)$ & $(0.000000275)$ & $(1.47 \mathrm{e}-13)$ & $(3.18 \mathrm{e}-39)$ \\
\hline \multirow[t]{2}{*}{ Health ODA commitments DAC } & 1.002 & 1.002 & $1.003^{*}$ & 1.001 & 1.002 \\
\hline & $(0.00152)$ & $(0.00280)$ & $(0.00147)$ & $(0.00366)$ & $(0.00597)$ \\
\hline \multirow[t]{2}{*}{ ODA projects in emergency response } & 1.061 & 0.655 & 1.289 & $16.11 * * *$ & 6.802 \\
\hline & $(0.194)$ & $(0.235)$ & $(0.311)$ & $(10.35)$ & $(9.090)$ \\
\hline \multirow[t]{2}{*}{ ODA project in water supply and sanitation } & $0.611 * * *$ & 0.731 & 0.615 & 0.397 & $0.194 * *$ \\
\hline & $(0.103)$ & $(0.209)$ & $(0.185)$ & $(0.328)$ & $(0.141)$ \\
\hline \multirow[t]{2}{*}{ ODA projects in agriculture /forestry / fishing } & $0.802 * *$ & 0.761 & 0.852 & $0.226 * * *$ & $0.153 * * *$ \\
\hline & $(0.0879)$ & $(0.135)$ & $(0.130)$ & $(0.117)$ & $(0.0910)$ \\
\hline \multirow[t]{2}{*}{ ODA projects in communications } & $1.280 * *$ & 1.012 & $1.528 * *$ & $8.538 * * *$ & $10.35 * * *$ \\
\hline & $(0.161)$ & $(0.210)$ & $(0.285)$ & $(5.380)$ & $(7.802)$ \\
\hline \multirow[t]{2}{*}{ ODA projects in actions relating to debt } & 0.981 & 1.488 & 0.789 & 0.880 & 0.578 \\
\hline & $(0.168)$ & $(0.450)$ & $(0.210)$ & $(0.700)$ & $(0.708)$ \\
\hline \multirow[t]{2}{*}{ ODA projects in education } & $1.162 *$ & 1.111 & $1.205^{* *}$ & 1.219 & $2.623^{*}$ \\
\hline & $(0.0892)$ & $(0.118)$ & $(0.104)$ & $(0.552)$ & (1.304) \\
\hline \multirow{2}{*}{ ODA projects in energy generation and supply } & $1.668 * * *$ & 1.430 & $1.744 * *$ & 1.008 & 11.19 \\
\hline & $(0.295)$ & $(0.404)$ & $(0.389)$ & $(0.723)$ & $(18.00)$ \\
\hline \multirow[t]{2}{*}{ ODA projects in government and civil society } & $1.168 * *$ & 1.081 & $1.244 * *$ & 1.183 & 1.351 \\
\hline & $(0.0833)$ & $(0.127)$ & $(0.122)$ & $(0.307)$ & $(0.671)$ \\
\hline ODA projects in industry / mining / construction & $0.612 *$ & 0.706 & $0.446^{*}$ & $0.0106 * * *$ & $0.0391 * * *$ \\
\hline & $(0.175)$ & $(0.324)$ & $(0.199)$ & $(0.00879)$ & $(0.0361)$ \\
\hline ODA projects in multiple sectors & $1.511 * * *$ & 0.995 & $1.949 * * *$ & $8.035 * * *$ & 5.597 \\
\hline & $(0.218)$ & $(0.229)$ & $(0.446)$ & $(3.885)$ & $(6.529)$ \\
\hline ODA projects in other social infrastructure & 0.959 & 1.014 & 0.897 & $0.0542 * * *$ & $0.00517 * * *$ \\
\hline & $(0.138)$ & $(0.140)$ & $(0.201)$ & $(0.0505)$ & $(0.00967)$ \\
\hline ODA projects in transport and storage & $1.205^{* *}$ & $1.420 * * *$ & 1.072 & 1.642 & 1.054 \\
\hline & $(0.0962)$ & $(0.161)$ & $(0.130)$ & $(0.789)$ & $(0.987)$ \\
\hline Year fixed effects & Yes & Yes & Yes & Yes & Yes \\
\hline Observations & 379 & 379 & 379 & 261 & 261 \\
\hline & Stanc & errors in $\mathrm{p}$ & entheses; $* \mathrm{p}<0.10$ & $* * \mathrm{p}<0.05, * *$ & $<<0.01$ \\
\hline
\end{tabular}

Table E1: Results of regression analyses using the corruption perception index as a measure of merit 


\begin{tabular}{|c|c|c|c|c|c|}
\hline & \multirow{2}{*}{\multicolumn{3}{|c|}{ Number of health ODA projects }} & & \\
\hline & & & & \multicolumn{2}{|c|}{ Amount of health ODA } \\
\hline & Total & Medical teams & $\begin{array}{l}\text { Infrastructure } \\
\text { / equipment } \\
\text { and drugs }\end{array}$ & Pooled & $\begin{array}{l}\text { Random } \\
\text { effects }\end{array}$ \\
\hline L.GDP per capita & $\begin{array}{l}0.944 * * * \\
(0.0206) \\
\end{array}$ & $\begin{array}{l}0.935^{* *} \\
(0.0256) \\
\end{array}$ & $\begin{array}{l}0.954 * * \\
(0.0210) \\
\end{array}$ & $\begin{array}{c}0.995 \\
(0.0513) \\
\end{array}$ & $\begin{array}{c}17.45^{* *} \\
(20.76) \\
\end{array}$ \\
\hline L.Public health expenditures & $\begin{array}{c}0.882 * * * \\
(0.0297) \\
\end{array}$ & $\begin{array}{c}0.960 \\
(0.0499) \\
\end{array}$ & $\begin{array}{l}0.828 * * \\
(0.0705) \\
\end{array}$ & $\begin{array}{c}0.496 * * * \\
(0.129) \\
\end{array}$ & $\begin{array}{c}0.0657 * * \\
(0.0889) \\
\end{array}$ \\
\hline L.Life expectancy & $\begin{array}{c}0.990 \\
(0.0117) \\
\end{array}$ & $\begin{array}{c}1.005 \\
(0.0144) \\
\end{array}$ & $\begin{array}{c}0.983 \\
(0.0148) \\
\end{array}$ & $\begin{array}{l}0.890^{* *} \\
(0.0414) \\
\end{array}$ & $\begin{array}{c}4.348^{* *} \\
(2.508) \\
\end{array}$ \\
\hline L.Population & $\begin{array}{c}0.994^{*} \\
(0.00343) \\
\end{array}$ & $\begin{array}{l}0.986 * * * \\
(0.00447) \\
\end{array}$ & $\begin{array}{c}0.996 \\
(0.00283) \\
\end{array}$ & $\begin{array}{c}0.995 \\
(0.00390) \\
\end{array}$ & $\begin{array}{c}0.699 * * \\
(0.103)\end{array}$ \\
\hline L.Voice and accountability index & $\begin{array}{c}1.123 \\
(0.0985) \\
\end{array}$ & $\begin{array}{c}0.949 \\
(0.128) \\
\end{array}$ & $\begin{array}{c}1.228 \\
(0.198) \\
\end{array}$ & $\begin{array}{c}1.184 \\
(0.628) \\
\end{array}$ & $\begin{array}{l}44.90 * * \\
(81.94) \\
\end{array}$ \\
\hline L.Natural resources rent & $\begin{array}{c}1.004 \\
(0.00266) \\
\end{array}$ & $\begin{array}{c}1.003 \\
(0.00393) \\
\end{array}$ & $\begin{array}{c}1.006 \\
(0.00426) \\
\end{array}$ & $\begin{array}{c}0.982 \\
(0.0229) \\
\end{array}$ & $\begin{array}{l}0.827 * * \\
(0.0706) \\
\end{array}$ \\
\hline L.Openness rate to China & $\begin{array}{c}1.006^{* *} \\
(0.00281)\end{array}$ & $\begin{array}{c}0.996 \\
(0.00299)\end{array}$ & $\begin{array}{l}1.009 * * \\
(0.00438)\end{array}$ & $\begin{array}{c}1.027 \\
(0.0230)\end{array}$ & $\begin{array}{l}0.935^{* *} \\
(0.0306) \\
\end{array}$ \\
\hline L.UNGA voting alignment & $\begin{array}{c}1.001 \\
(0.00248) \\
\end{array}$ & $\begin{array}{c}1.005 \\
(0.00401) \\
\end{array}$ & $\begin{array}{c}0.998 \\
(0.00390) \\
\end{array}$ & $\begin{array}{c}1.018 * * \\
(0.00904) \\
\end{array}$ & $\begin{array}{c}0.952 \\
(0.0422) \\
\end{array}$ \\
\hline L.Taiwan recognition & $\begin{array}{c}0.0440 * * * \\
(0.0443) \\
\end{array}$ & $\begin{array}{c}0.0856 * * \\
(0.0884) \\
\end{array}$ & $\begin{array}{c}4.29 \mathrm{e}-08 * * * \\
(2.11 \mathrm{e}-08) \\
\end{array}$ & $\begin{array}{c}3.62 \mathrm{e}-13^{* * * *} \\
(2.63 \mathrm{e}-13)\end{array}$ & $\begin{array}{c}3.42 \mathrm{e}-49 * * * \\
(1.07 \mathrm{e}-47)\end{array}$ \\
\hline Health ODA commitments DAC & $\begin{array}{c}1.002 \\
(0.00170)\end{array}$ & $\begin{array}{c}1.002 \\
(0.00278)\end{array}$ & $\begin{array}{c}1.002 \\
(0.00170) \\
\end{array}$ & $\begin{array}{c}1.001 \\
(0.00325) \\
\end{array}$ & $\begin{array}{c}1.001 \\
(0.00579) \\
\end{array}$ \\
\hline ODA projects in emergency response & $\begin{array}{c}1.013 \\
(0.184) \\
\end{array}$ & $\begin{array}{c}0.623 \\
(0.233) \\
\end{array}$ & $\begin{array}{c}1.223 \\
(0.305) \\
\end{array}$ & $\begin{array}{c}17.74 * * * \\
(10.85) \\
\end{array}$ & $\begin{array}{c}6.944 \\
(8.790) \\
\end{array}$ \\
\hline ODA project in water supply and sanitation & $\begin{array}{c}0.622 * * * \\
(0.107) \\
\end{array}$ & $\begin{array}{c}0.709 \\
(0.203) \\
\end{array}$ & $\begin{array}{c}0.634 \\
(0.194) \\
\end{array}$ & $\begin{array}{c}0.369 \\
(0.291) \\
\end{array}$ & $\begin{array}{l}0.124 * * * \\
(0.0862) \\
\end{array}$ \\
\hline ODA projects in agriculture /forestry / fishing & $\begin{array}{c}0.825^{*} \\
(0.0865)\end{array}$ & $\begin{array}{c}0.772 \\
(0.129) \\
\end{array}$ & $\begin{array}{c}0.892 \\
(0.127) \\
\end{array}$ & $\begin{array}{c}0.247 * * * \\
(0.118)\end{array}$ & $\begin{array}{c}0.161 * * * \\
(0.107)\end{array}$ \\
\hline ODA projects in communications & $\begin{array}{l}1.255^{*} \\
(0.168) \\
\end{array}$ & $\begin{array}{c}0.984 \\
(0.210) \\
\end{array}$ & $\begin{array}{l}1.497 * * \\
(0.276) \\
\end{array}$ & $\begin{array}{c}8.341 * * * \\
(5.299) \\
\end{array}$ & $\begin{array}{c}9.337 * * * \\
(7.118) \\
\end{array}$ \\
\hline ODA projects in actions relating to debt & $\begin{array}{c}1.117 \\
(0.188) \\
\end{array}$ & $\begin{array}{c}1.543 \\
(0.434) \\
\end{array}$ & $\begin{array}{c}1.008 \\
(0.236) \\
\end{array}$ & $\begin{array}{c}1.077 \\
(0.803) \\
\end{array}$ & $\begin{array}{c}0.277 \\
(0.287) \\
\end{array}$ \\
\hline ODA projects in education & $\begin{array}{l}1.168 * * \\
(0.0891) \\
\end{array}$ & $\begin{array}{c}1.134 \\
(0.120) \\
\end{array}$ & $\begin{array}{l}1.191^{* * *} \\
(0.0967) \\
\end{array}$ & $\begin{array}{c}1.115 \\
(0.463) \\
\end{array}$ & $\begin{array}{c}2.084 \\
(1.113) \\
\end{array}$ \\
\hline ODA projects in energy generation and supply & $\begin{array}{c}1.612 * * * \\
(0.276)\end{array}$ & $\begin{array}{c}1.406 \\
(0.386) \\
\end{array}$ & $\begin{array}{l}1.675^{* * *} \\
(0.359) \\
\end{array}$ & $\begin{array}{c}1.138 \\
(0.851) \\
\end{array}$ & $\begin{array}{l}15.98^{*} \\
(24.95) \\
\end{array}$ \\
\hline ODA projects in government and civil society & $\begin{array}{c}1.125 \\
(0.0868) \\
\end{array}$ & $\begin{array}{c}1.076 \\
(0.130) \\
\end{array}$ & $\begin{array}{c}1.166 \\
(0.118) \\
\end{array}$ & $\begin{array}{c}1.131 \\
(0.281) \\
\end{array}$ & $\begin{array}{c}1.106 \\
(0.481) \\
\end{array}$ \\
\hline ODA projects in industry / mining / construction & $\begin{array}{c}0.625 \\
(0.182) \\
\end{array}$ & $\begin{array}{c}0.690 \\
(0.296)\end{array}$ & $\begin{array}{l}0.465^{*} \\
(0.216)\end{array}$ & $\begin{array}{c}0.00968 * * * \\
(0.00902)\end{array}$ & $\begin{array}{c}0.0657 * * * \\
(0.0570)\end{array}$ \\
\hline ODA projects in multiple sectors & $\begin{array}{c}1.415^{* *} \\
(0.213) \\
\end{array}$ & $\begin{array}{c}0.973 \\
(0.235) \\
\end{array}$ & $\begin{array}{c}1.796^{* *} \\
(0.412) \\
\end{array}$ & $\begin{array}{c}6.833 * * * \\
(3.034) \\
\end{array}$ & $\begin{array}{c}2.596 \\
(2.118) \\
\end{array}$ \\
\hline ODA projects in other social infrastructure & $\begin{array}{c}0.954 \\
(0.135) \\
\end{array}$ & $\begin{array}{c}1.008 \\
(0.141) \\
\end{array}$ & $\begin{array}{c}0.896 \\
(0.203) \\
\end{array}$ & $\begin{array}{c}0.0638^{* * * *} \\
(0.0543)\end{array}$ & $\begin{array}{c}0.00676^{* * * *} \\
(0.0118)\end{array}$ \\
\hline ODA projects in transport and storage & $\begin{array}{l}1.205^{* *} \\
(0.0977) \\
\end{array}$ & $\begin{array}{c}1.412 * * * \\
(0.167)\end{array}$ & $\begin{array}{c}1.079 \\
(0.130) \\
\end{array}$ & $\begin{array}{c}1.580 \\
(0.841) \\
\end{array}$ & $\begin{array}{c}0.876 \\
(0.762) \\
\end{array}$ \\
\hline Year fixed effects & Yes & Yes & Yes & Yes & Yes \\
\hline Observations & 389 & 389 & 389 & 268 & 268 \\
\hline
\end{tabular}

Table E2: Results of regression analyses using the voice and accountability index as a measure of merit 


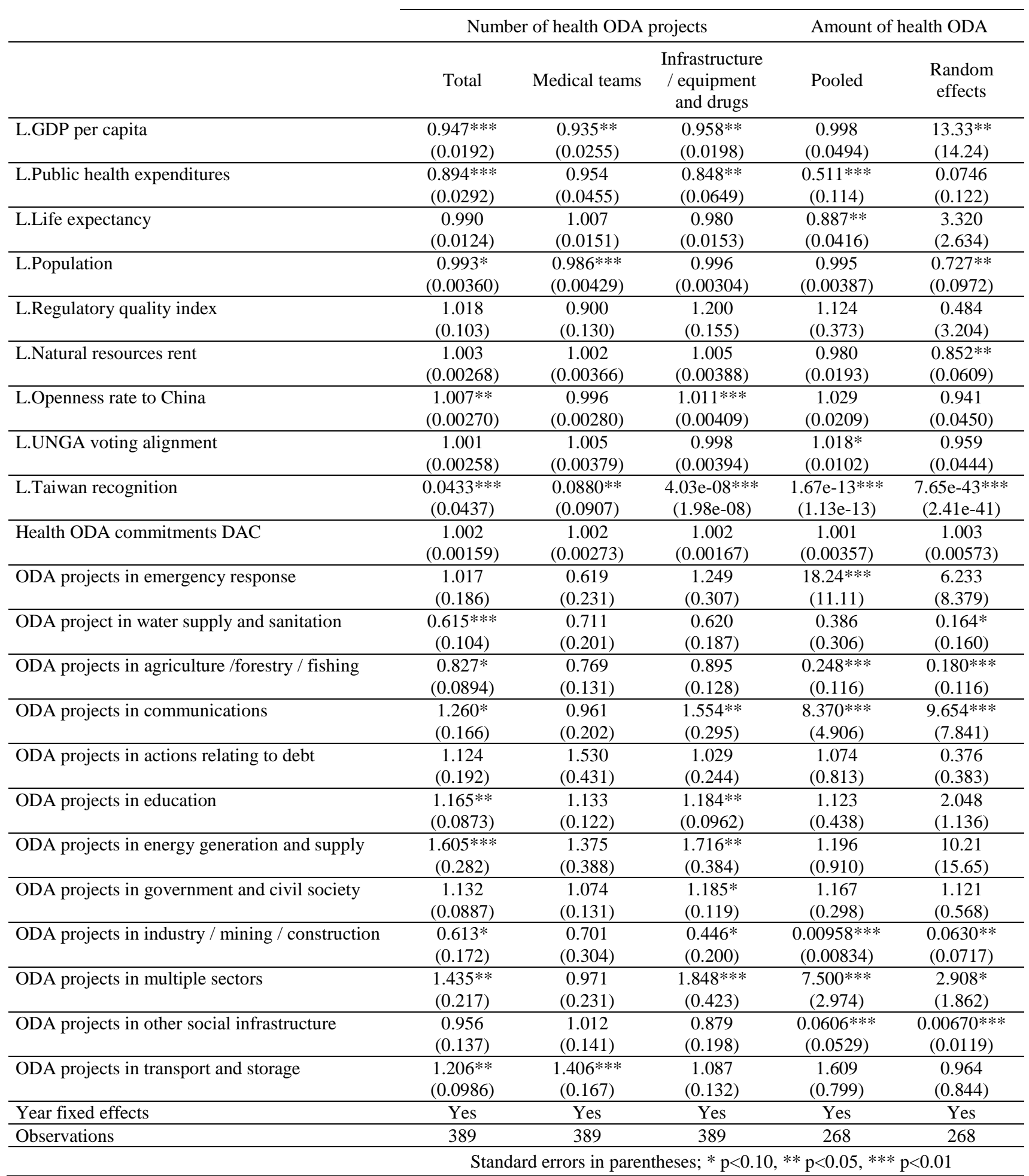

Table E3: Results of regression analyses using the regulatory quality index as a measure of merit 


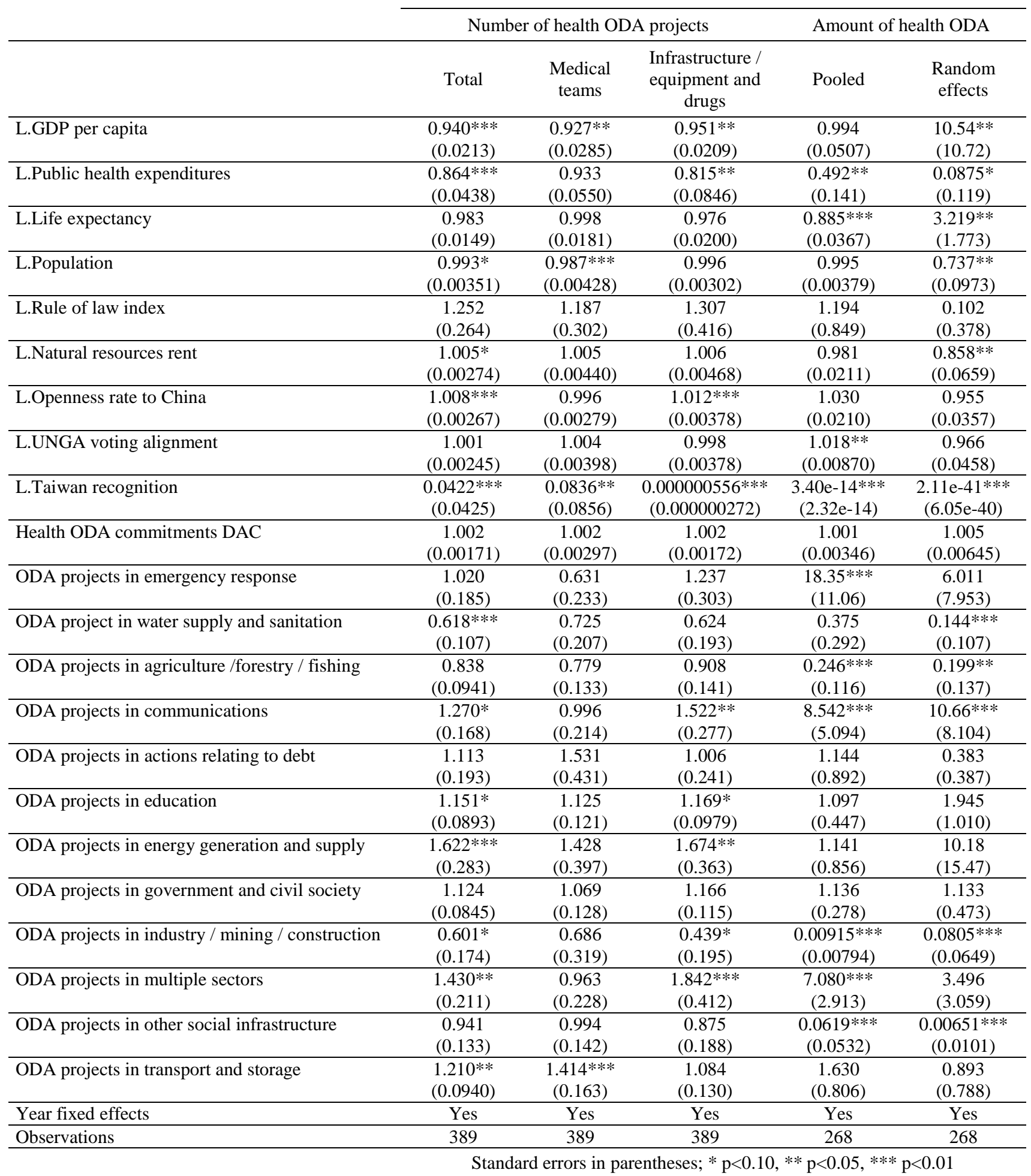

Table E4: Results of regression analyses using the rule of law index as a measure of merit 


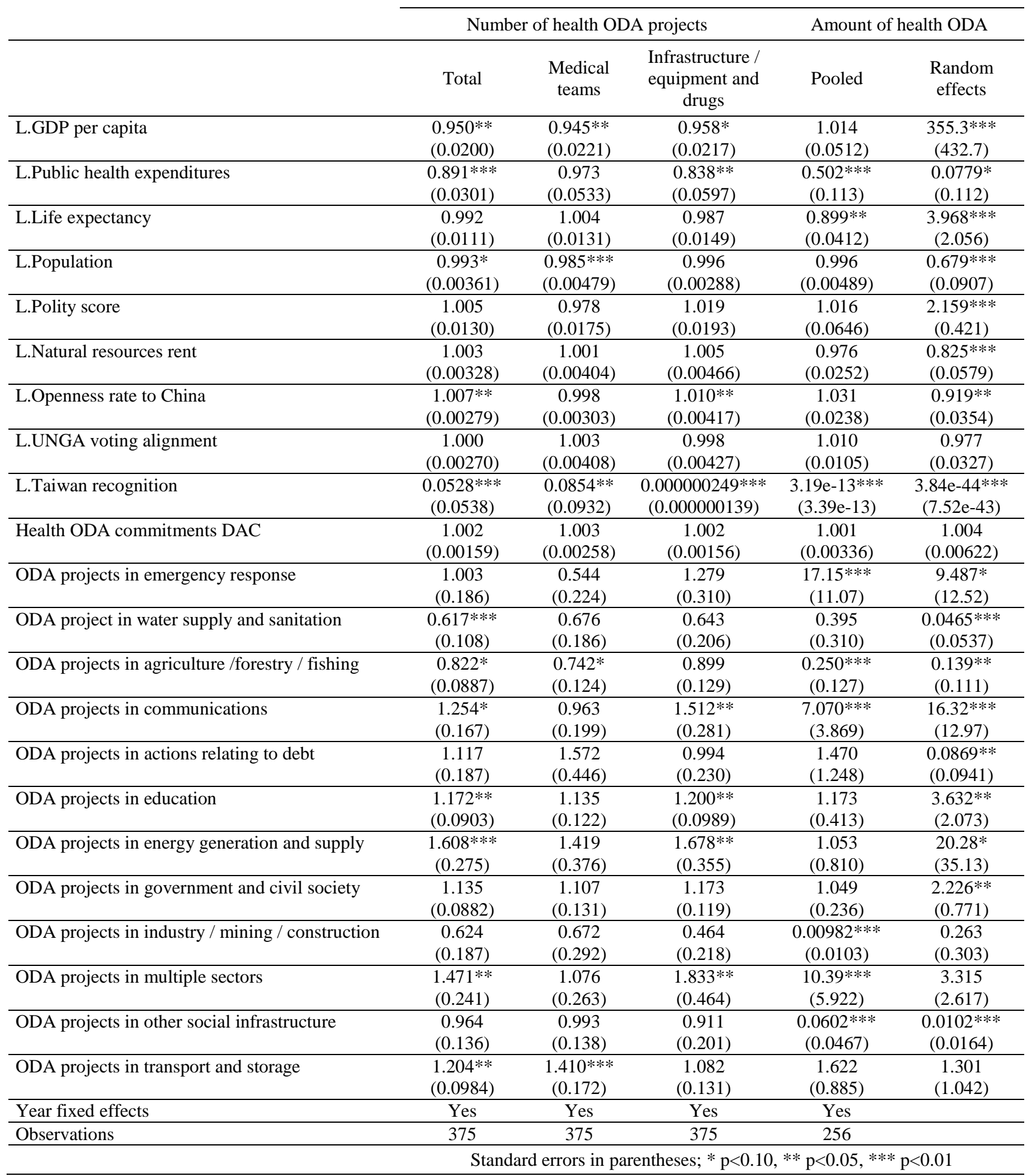

Table E5: Results of regression analyses using the polity score as a measure of merit 


\section{Appendix F: Results of regression analyses using alternative measures of economic interests}

\begin{tabular}{|c|c|c|c|c|c|}
\hline & \multirow{2}{*}{\multicolumn{3}{|c|}{ Number of health ODA projects }} & \multirow{2}{*}{\multicolumn{2}{|c|}{ Amount of health ODA }} \\
\hline & & & & & \\
\hline & Total & $\begin{array}{l}\text { Medical } \\
\text { teams }\end{array}$ & $\begin{array}{c}\text { Infrastructure / } \\
\text { equipment and } \\
\text { drugs }\end{array}$ & Pooled & $\begin{array}{l}\text { Random } \\
\text { effects }\end{array}$ \\
\hline \multirow[t]{2}{*}{ L.GDP per capita } & $0.945 * * *$ & $0.929 * *$ & $0.958 * *$ & 0.989 & $13.28 * * *$ \\
\hline & $(0.0192)$ & $(0.0273)$ & $(0.0187)$ & $(0.0471)$ & $(13.33)$ \\
\hline \multirow[t]{2}{*}{ L.Public health expenditures } & $0.877 * * *$ & 0.926 & $0.850 * *$ & $0.521 * * *$ & $0.0778 * *$ \\
\hline & $(0.0337)$ & $(0.0497)$ & $(0.0663)$ & $(0.128)$ & $(0.0962)$ \\
\hline \multirow[t]{2}{*}{ L.Life expectancy } & 0.986 & 0.996 & 0.985 & $0.895 * * *$ & $3.849 * *$ \\
\hline & $(0.0141)$ & $(0.0171)$ & $(0.0183)$ & $(0.0379)$ & $(2.375)$ \\
\hline \multirow[t]{2}{*}{ L.Population } & $0.993 * *$ & $0.987 * * *$ & 0.996 & 0.995 & $0.742 *$ \\
\hline & $(0.00339)$ & $(0.00412)$ & $(0.00305)$ & $(0.00392)$ & $(0.116)$ \\
\hline \multirow[t]{2}{*}{ L.Control of corruption index } & 1.144 & 1.215 & 1.056 & 1.121 & 36.07 \\
\hline & $(0.193)$ & $(0.228)$ & $(0.280)$ & $(0.724)$ & $(94.81)$ \\
\hline \multirow[t]{2}{*}{ L.Natural resources rent } & $1.005^{*}$ & 1.005 & 1.005 & 0.984 & $0.833 * *$ \\
\hline & $(0.00286)$ & $(0.00394)$ & $(0.00487)$ & $(0.0191)$ & $(0.0746)$ \\
\hline \multirow[t]{2}{*}{ L.Imports from China } & $1.003 * *$ & $0.997 *$ & $1.005 * * *$ & 1.007 & $0.956 * * *$ \\
\hline & $(0.00130)$ & $(0.00159)$ & $(0.00173)$ & $(0.00814)$ & $(0.0146)$ \\
\hline \multirow[t]{2}{*}{ L.UNGA voting alignment } & 1.001 & 1.005 & 0.999 & $1.018^{*}$ & 0.953 \\
\hline & $(0.00257)$ & $(0.00401)$ & $(0.00402)$ & $(0.00935)$ & $(0.0378)$ \\
\hline \multirow[t]{2}{*}{ L.Taiwan recognition } & $0.0408 * * *$ & $0.0817 * *$ & $0.000000111^{* * * *}$ & $1.83 \mathrm{e}-13 * * *$ & $3.90 \mathrm{e}-42 * * *$ \\
\hline & $(0.0413)$ & $(0.0842)$ & $(5.36 \mathrm{e}-08)$ & $(1.21 \mathrm{e}-13)$ & $(1.26 \mathrm{e}-40)$ \\
\hline \multirow[t]{2}{*}{ Health ODA commitments DAC } & 1.002 & 1.002 & 1.002 & 1.001 & 1.004 \\
\hline & $(0.00159)$ & $(0.00285)$ & $(0.00158)$ & $(0.00361)$ & $(0.00607)$ \\
\hline \multirow[t]{2}{*}{ ODA projects in emergency response } & 1.039 & 0.717 & 1.203 & $17.14 * * *$ & 3.134 \\
\hline & $(0.184)$ & $(0.245)$ & $(0.291)$ & $(10.25)$ & $(3.822)$ \\
\hline \multirow[t]{2}{*}{ ODA project in water supply and sanitation } & $0.616 * * *$ & 0.719 & 0.624 & 0.382 & $0.109 * * *$ \\
\hline & $(0.104)$ & $(0.210)$ & $(0.188)$ & $(0.306)$ & $(0.0792)$ \\
\hline \multirow[t]{2}{*}{ ODA projects in agriculture /forestry / fishing } & $0.832 *$ & 0.783 & 0.893 & $0.249 * * *$ & $0.217 * *$ \\
\hline & $(0.0896)$ & $(0.133)$ & $(0.133)$ & $(0.120)$ & $(0.139)$ \\
\hline \multirow[t]{2}{*}{ ODA projects in communications } & $1.261 *$ & 0.989 & $1.514 * *$ & $7.827 * * *$ & $9.242 * * *$ \\
\hline & $(0.169)$ & $(0.217)$ & $(0.280)$ & $(4.753)$ & $(7.851)$ \\
\hline \multirow[t]{2}{*}{ ODA projects in actions relating to debt } & 1.124 & 1.515 & 1.029 & 1.090 & 0.359 \\
\hline & $(0.192)$ & $(0.431)$ & $(0.244)$ & $(0.857)$ & $(0.387)$ \\
\hline \multirow[t]{2}{*}{ ODA projects in education } & $1.149 *$ & 1.112 & $1.179^{*}$ & 1.148 & 1.707 \\
\hline & $(0.0890)$ & $(0.115)$ & $(0.106)$ & $(0.450)$ & $(1.008)$ \\
\hline \multirow[t]{2}{*}{ ODA projects in energy generation and supply } & $1.614 * * *$ & 1.442 & $1.638 * *$ & 1.060 & 8.023 \\
\hline & $(0.282)$ & $(0.396)$ & $(0.356)$ & $(0.799)$ & $(11.15)$ \\
\hline \multirow[t]{2}{*}{ ODA projects in government and civil society } & 1.130 & 1.073 & 1.172 & 1.125 & 0.982 \\
\hline & $(0.0860)$ & $(0.128)$ & $(0.116)$ & $(0.277)$ & $(0.470)$ \\
\hline \multirow[t]{2}{*}{ ODA projects in industry / mining / construction } & $0.602 *$ & 0.660 & $0.455^{*}$ & $0.00973 * * *$ & $0.102 * *$ \\
\hline & $(0.170)$ & $(0.292)$ & $(0.203)$ & $(0.00864)$ & $(0.111)$ \\
\hline ODA projects in multiple sectors & $1.439 * *$ & 0.977 & $1.838 * * *$ & $6.860 * * *$ & $3.361 *$ \\
\hline & $(0.220)$ & $(0.233)$ & $(0.419)$ & $(2.786)$ & $(2.275)$ \\
\hline ODA projects in other social infrastructure & 0.956 & 0.996 & 0.901 & $0.0644 * * *$ & $0.00870^{* * *}$ \\
\hline & $(0.137)$ & $(0.142)$ & $(0.204)$ & $(0.0574)$ & $(0.0145)$ \\
\hline ODA projects in transport and storage & $1.214 * *$ & $1.417 * * *$ & 1.086 & 1.638 & 0.771 \\
\hline & $(0.0975)$ & $(0.159)$ & $(0.137)$ & $(0.754)$ & $(0.660)$ \\
\hline Year fixed effects & Yes & Yes & Yes & Yes & Yes \\
\hline Observations & 396 & 396 & 396 & 273 & 273 \\
\hline
\end{tabular}

Table F1: Results of regression analyses using imports from China as a percentage of GDP as a measure of economic interests 


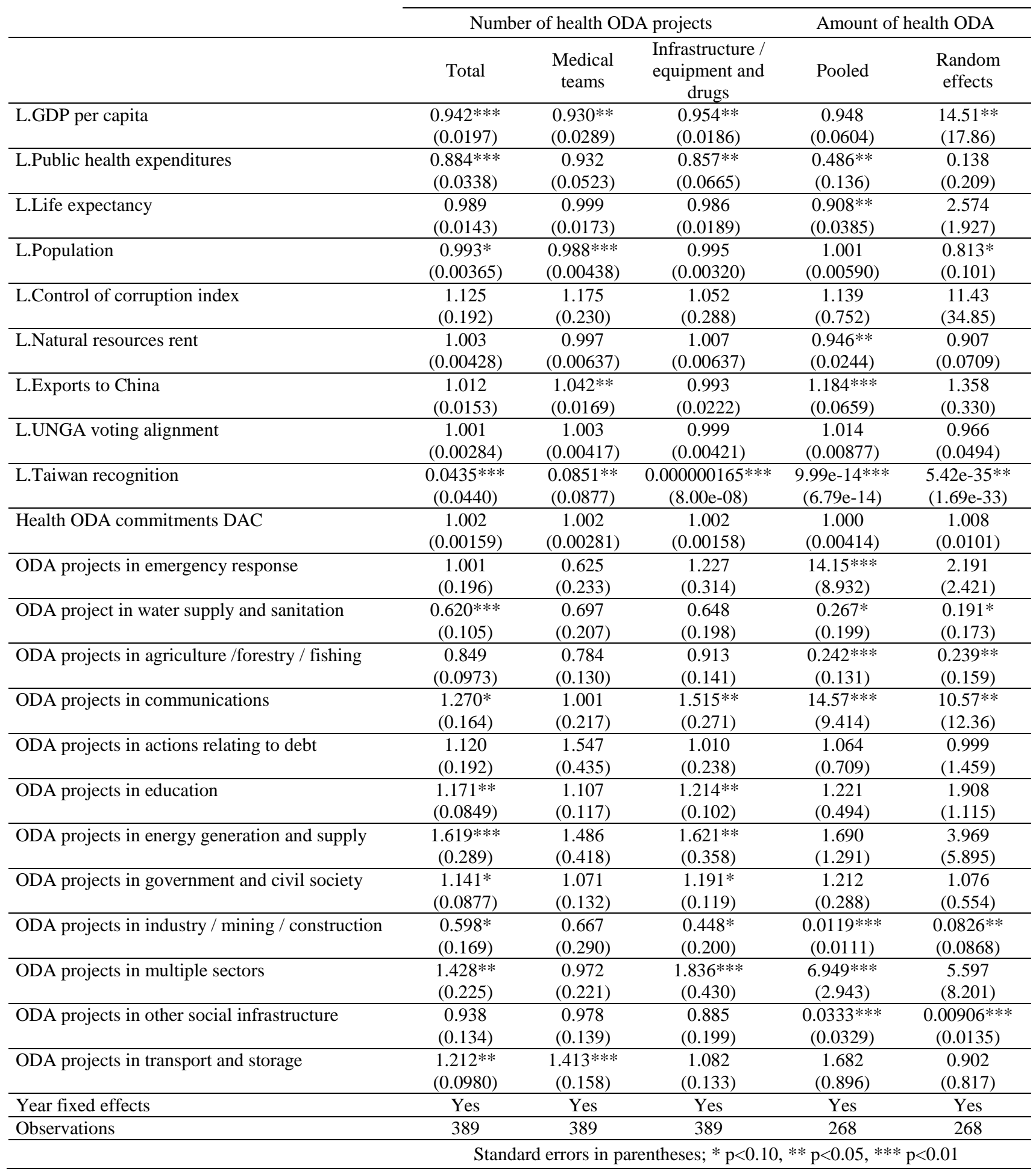

Table F2: Results of regression analyses using exports to China as a percentage of GDP as a measure of economic interests 


\begin{tabular}{|c|c|c|c|c|c|}
\hline & \multirow{2}{*}{\multicolumn{3}{|c|}{ Number of health ODA projects }} & \multirow{2}{*}{\multicolumn{2}{|c|}{ Amount of health ODA }} \\
\hline & & & & & \\
\hline & Total & $\begin{array}{c}\text { Medical } \\
\text { teams }\end{array}$ & $\begin{array}{l}\text { Infrastructure / } \\
\text { equipment and } \\
\text { drugs }\end{array}$ & Pooled & $\begin{array}{l}\text { Random } \\
\text { effects }\end{array}$ \\
\hline \multirow[t]{2}{*}{ L.GDP per capita } & $0.940 * * *$ & $0.924 * *$ & $0.953 * *$ & 0.966 & $10.43 * *$ \\
\hline & $(0.0199)$ & $(0.0297)$ & $(0.0189)$ & $(0.0532)$ & $(11.90)$ \\
\hline \multirow[t]{2}{*}{ L.Public health expenditures } & $0.885 * *$ & 1.009 & $0.814 * *$ & $0.394 * * *$ & 0.114 \\
\hline & $(0.0526)$ & $(0.0769)$ & $(0.0769)$ & $(0.110)$ & $(0.228)$ \\
\hline \multirow[t]{2}{*}{ L.Life expectancy } & 0.983 & 0.998 & 0.976 & $0.853 * * *$ & 2.204 \\
\hline & $(0.0178)$ & $(0.0219)$ & $(0.0213)$ & $(0.0424)$ & $(1.482)$ \\
\hline \multirow[t]{2}{*}{ L.Population } & $0.993^{*}$ & $0.987 * * *$ & 0.995 & $0.993 * *$ & $0.759 * *$ \\
\hline & $(0.00370)$ & $(0.00456)$ & $(0.00324)$ & $(0.00364)$ & $(0.0919)$ \\
\hline \multirow[t]{2}{*}{ L.Control of corruption index } & 1.178 & 1.123 & 1.233 & 2.330 & 1.245 \\
\hline & $(0.226)$ & $(0.251)$ & $(0.342)$ & $(1.433)$ & $(4.196)$ \\
\hline \multirow[t]{2}{*}{ L.Natural resources rent } & $1.005^{*}$ & 1.001 & 1.007 & 0.994 & 1.005 \\
\hline & $(0.00304)$ & $(0.00456)$ & $(0.00489)$ & $(0.0207)$ & $(0.132)$ \\
\hline \multirow[t]{2}{*}{ L.FDI from China } & 1.000 & 1.000 & 1.000 & 1.000 & 1.008 \\
\hline & $(0.000185)$ & $(0.000193)$ & $(0.000283)$ & $(0.000277)$ & $(0.00545)$ \\
\hline \multirow[t]{2}{*}{ L.UNGA voting alignment } & 1.001 & 1.006 & 0.997 & 1.002 & 1.009 \\
\hline & $(0.00373)$ & $(0.00561)$ & $(0.00502)$ & $(0.0142)$ & $(0.0681)$ \\
\hline \multirow[t]{2}{*}{ L.Taiwan recognition } & $0.362 * * *$ & 0.609 & $0.000000842 * * *$ & $4.40 \mathrm{e}-10 * * *$ & $1.05 \mathrm{e}-14 * * *$ \\
\hline & $(0.0775)$ & $(0.201)$ & $(0.000000931)$ & $(6.22 \mathrm{e}-10)$ & $(3.00 \mathrm{e}-14)$ \\
\hline \multirow[t]{2}{*}{ Health ODA commitments DAC } & 1.002 & 1.001 & 1.002 & 1.000 & 1.005 \\
\hline & $(0.00172)$ & $(0.00339)$ & $(0.00165)$ & $(0.00311)$ & $(0.00722)$ \\
\hline \multirow[t]{2}{*}{ ODA projects in emergency response } & 0.869 & 0.559 & 0.994 & $30.78 * * *$ & 8.024 \\
\hline & $(0.156)$ & $(0.230)$ & $(0.237)$ & $(24.51)$ & $(13.14)$ \\
\hline \multirow[t]{2}{*}{ ODA project in water supply and sanitation } & $0.660 * *$ & 0.801 & 0.683 & $0.241^{*}$ & $0.101 * * *$ \\
\hline & $(0.113)$ & $(0.244)$ & $(0.206)$ & $(0.207)$ & $(0.0890)$ \\
\hline \multirow[t]{2}{*}{ ODA projects in agriculture /forestry / fishing } & $0.828^{*}$ & 0.773 & 0.883 & $0.293 * * *$ & 0.270 \\
\hline & $(0.0911)$ & $(0.135)$ & $(0.138)$ & $(0.135)$ & $(0.253)$ \\
\hline \multirow[t]{2}{*}{ ODA projects in communications } & $1.280^{*}$ & 0.949 & $1.567 * *$ & $6.829 * * *$ & $10.50 * *$ \\
\hline & $(0.165)$ & $(0.234)$ & $(0.277)$ & $(4.324)$ & $(12.36)$ \\
\hline \multirow[t]{2}{*}{ ODA projects in actions relating to debt } & 1.134 & $1.761 *$ & 0.912 & 1.433 & 2.031 \\
\hline & $(0.230)$ & $(0.537)$ & $(0.268)$ & $(1.159)$ & $(3.003)$ \\
\hline \multirow[t]{2}{*}{ ODA projects in education } & 1.126 & 1.032 & $1.165^{*}$ & 0.948 & 1.826 \\
\hline & $(0.0821)$ & $(0.110)$ & $(0.103)$ & $(0.327)$ & $(1.292)$ \\
\hline \multirow[t]{2}{*}{ ODA projects in energy generation and supply } & $1.542 * *$ & 1.487 & 1.422 & 5.523 & $19.26^{*}$ \\
\hline & $(0.270)$ & $(0.468)$ & $(0.339)$ & $(6.604)$ & $(29.55)$ \\
\hline \multirow[t]{2}{*}{ ODA projects in government and civil society } & $1.163^{*}$ & 1.065 & $1.247 * *$ & $1.400 * *$ & 1.687 \\
\hline & $(0.0902)$ & $(0.137)$ & $(0.123)$ & $(0.228)$ & $(1.104)$ \\
\hline ODA projects in industry / mining / construction & $0.584^{*}$ & 0.687 & $0.410 * *$ & $0.00445^{* * * *}$ & $0.00811 *$ \\
\hline & $(0.172)$ & $(0.313)$ & $(0.181)$ & $(0.00588)$ & $(0.0217)$ \\
\hline ODA projects in multiple sectors & $1.354^{*}$ & 1.031 & $1.571 *$ & $5.899 * * *$ & 12.19 \\
\hline & $(0.225)$ & $(0.274)$ & $(0.365)$ & $(2.535)$ & $(20.70)$ \\
\hline ODA projects in other social infrastructure & 0.939 & 1.038 & 0.854 & $0.0814 * * *$ & $0.00823 * *$ \\
\hline & $(0.139)$ & $(0.138)$ & $(0.193)$ & $(0.0624)$ & $(0.0183)$ \\
\hline ODA projects in transport and storage & $1.213 * *$ & $1.435 * * *$ & 1.075 & 1.026 & 0.528 \\
\hline & $(0.105)$ & $(0.172)$ & $(0.131)$ & $(0.493)$ & $(0.754)$ \\
\hline Year fixed effects & Yes & Yes & Yes & Yes & Yes \\
\hline Observations & 293 & 293 & 293 & 199 & 199 \\
\hline & Stand & $\mathrm{d}$ errors in $\mathrm{pe}$ & entheses; * $p<0.10$ & $* * \mathrm{p}<0.05, *$ & $<<0.01$ \\
\hline
\end{tabular}

Table F3: Results of regression analyses using FDI from China as a measure of economic interests 


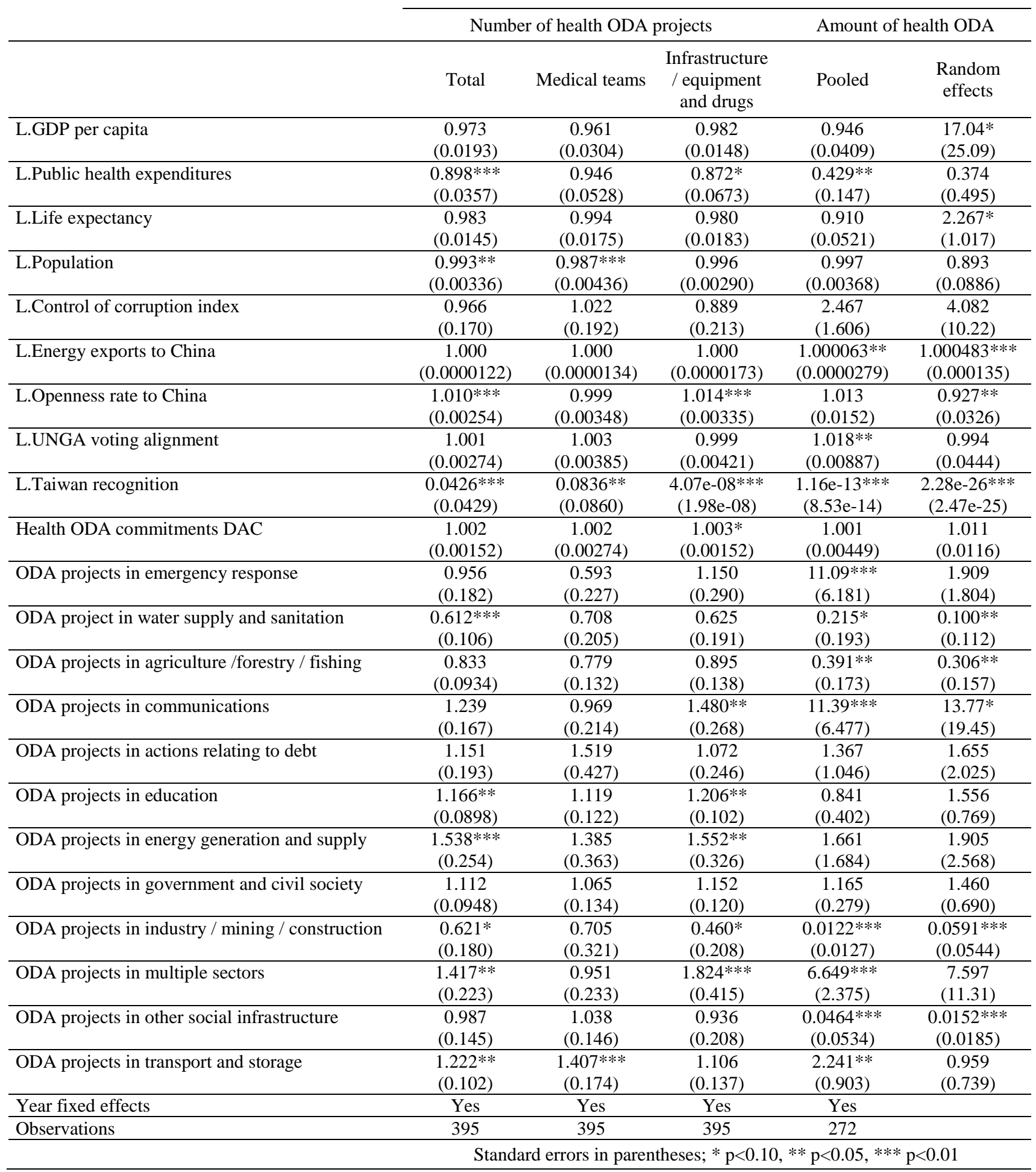

Table F4: Results of regression analyses using energy exports to China as a measure of economic interests 